\title{
ADVOCACY OR FOLLY: THE ALLEGED LUNATICS' FRIEND SOCIETY, 1845-63
}

\author{
by
}

\author{
NICHOLAS HERVEY*
}

\begin{abstract}
Some of the names we have seen announced suggest to us the possibility that the promoters of this scheme are not altogether free from motives of self-preservation... we think they should be satisfied to take care of themselves, without tendering their services to all who happen to be in the same position. (The Times, 27 March 1846.)
\end{abstract}

Throughout its history, the Alleged Lunatics' Friend Society ${ }^{1}$ attracted gratuitous abuse from the popular press and medical journals. It failed to mobilize public support and was constantly treated with disdain by those authorities responsible for the care and treatment of lunatics. Nevertheless, it made a substantial contribution to patients' rights and in many other respects was a distinguished predecessor to organizations such as the Lunacy Law Reform Association, ${ }^{2}$ the National Society for Lunacy Reform, ${ }^{3}$ and, more recently, MIND. Little has been written about the ALFS and its members, but their interest in the field of mental health was catholic, and their persective wider than has been generally acknowledged. Kathleen Jones portrayed their activities within a narrow legalistic framework, and suggested that they exaggerated the extent to which sane members of the public were forcibly incarcerated in defiance of the laws. ${ }^{4}$ This opinion has been echoed elsewhere, but does not represent wider aspects of the Society's campaign, which sought to effect changes in the way lunatics were perceived and treated. Parry-Jones did concede that the Society was "not unimportant", but he too saw it as having a circumscribed role related to civil liberties. ${ }^{5}$ The object of this article is to present a more detailed account of the Society,

*Nicholas Hervey, BA, 58 Old Dover Road, Blackheath, London SE3 8SY.

${ }^{1}$ Hereinafter referred to as ALFS.

2 This association was extremely polemical, and was led by Louisa Lowe, a vicar's wife, who had been incarcerated by her husband because of her spiritualism. She had left him and claimed he was trying to get hold of her property. Founded in 1873, it died out around 1885.

${ }^{3}$ This Society started life as the National Council for Lunacy Reform, and was founded following two private conferences on the issue of lunacy reform held at the Minerva Cafe on 29 April and 19 May 1920. Its objects were: to promote research into the causes of mental instability; to investigate the present system of care and treatment, and its results; to secure the provision of hostels for early cases; to safeguard the liberty of the subject; to reduce the burden of ever-increasing asylum expenditure; and to educate public opinion on the subject of mental disorder. It was clearly influential in securing a Royal commision in 1926, and was disappointed by subsequent legislation in 1929. It had branch organizations outside London, and included two members who wrote books on the asylum system, J. E. Parley and Dr. M. Lomax. (There are three minute books for this Society held at the offices of MIND, 22 Wimpole Street, London. It was based in London variously at 32/33 Avenue Chambers, Southampton Row; 90 Avenue Chambers; and 44 Wimpole Street.)

${ }^{4}$ K. Jones, Mental health and social policy 1845-1959, London, Routledge \& Kegan Paul, 1960, p. 35.

${ }^{5}$ William L1. Parry-Jones, The trade in lunacy: a study of private madhouses in England in the eighteenth and nineteenth centuries, London, Routledge \& Kegan Paul, 1972, pp. 89.98. 


\section{N. Hervey}

its history and aims, and provide a corrective to the view that it had a relatively insignificant impact on the development of nineteenth-century psychiatric practice. It is a mistake to see this organization as solely, or even primarily, concerned with the issue of certification. Certainly, it was anxious to improve some aspects of the admission process. In particular, the Society hoped a jury trial before admission and more detailed medical certificates would prevent collusion in wrongful incarceration of the sane. Equally important, however, were the provision of an effective appeal structure against confinement and automatic review of the necessity for continued detention. Historians, by concentrating on a few noted cases of illegal confinement, ${ }^{6}$ have obscured many important features of the Society's campaign, notably its role as alter ego to the Lunacy Commission, its influence on legislative change, its exposure of bad asylums, and its attempt to raise public consciousness of the threat psychiatric practice posed to civil liberties generally.

Before examining these issues further, I shall outline developments before the mid-nineteenth century that constitute a backdrop to public concern about certification, wrongful detention of the sane, and ill-treatment of the insane. Later sections will cover the personnel and objectives of the Society, and its four avenues of campaign: Parliament, the courts, the local magistrates, and public meetings and lectures. Finally, I shall examine the Society's relations with the medical profession and the Lunacy Commission, and assess its contribution to psychiatric practice.

\section{BACKGROUND}

In 1763, an article in the Gentleman's Magazine mentioned innocents being "decoyed" into private madhouses, "stripped by banditti", and "forcibly reduced by physic". Such emotive language fuelled public disquiet about madhouses and the ease with which unscrupulous parties could confine a person for life, without appeal. Defoe had been among the first to question the practice of these institutions in Augusta Triumphans (1728). He attacked the way husbands were able to confine their wives for the most spurious of reasons, and suggested that madhouses should be regularly inspected. ${ }^{7}$ Subsequently, Smollett stoked the fire with his novel, Sir Launcelot Greaves (1762). In this, the eponymous hero again complained of illegal confinement, but also of the low-bred, mercenary barbarians who made a living from asylums. ${ }^{8}$ Significantly for future controversy concerning involuntary detention, Sir Launcelot also highlighted the problem of delineating boundaries between sanity and madness, professing that he thought "one half of the nation mad-and the other not very sound". These boundaries were shifting, as MacDonald has shown, with the educated élite gradually abandoning their beliefs in divine inspiration and demonology during

\footnotetext{
${ }^{6}$ The cases of Turner, Leech, and Ruck in 1858 have been widely quoted, and also that of Frederick Windham in 1861. See J. L. and B. Hammond, Lord Shaftesbury, London, Constable, 1923, pp. $204-208$. Also. P. McCandless, 'Liberty and lunacy: the Victorians and wrongful confinement', in A Scull (editor), Madhouses, mad-doctors and madmen: the social history of psychiatry in the Victorian era, London, Athlone Press, 1981.

${ }^{7}$ D. Defoe, Augusta Triumphans: or, the way to make London the most flourishing city in the universe, London, 1728, pp. 30-34. The history of ex-patients campaigning against the practices of madhouses also started at this time. See A. Cruden, The London citizen exceedingly injured: or a British inquisition display'd, London, T. Cooper, 1739.

${ }^{8}$ T. Smollett, The adventures of Sir Launcelot Greaves, London, 1762, vol. 2, pp. 228-230.
} 


\section{The Alleged Lunatics' Friend Society}

the late seventeenth and early eighteenth centuries. ${ }^{9}$ As madness increasingly fell within the purview of physicians, rather than lay and clerical healers, the former became recognized as the major group defining and legitimating insanity, even though they still had no official status in that respect. As the number of madhouses grew, the need for an offical group to carry out identification and committal procedures became increasingly evident. ${ }^{10}$

Following earlier misgivings about private asylums, an Act of 1774 prescribed a rudimentary certification system. This applied only to private patients, leaving paupers unprotected. ${ }^{11}$ The new law empowered anyone declaring himself to be an apothecary, surgeon, or physician to sign a certificate, but many of these men were unqualified and inexperienced. Indeed as late as 1850, many medical men had little or no experience of mental illness, and civil libertarians became increasingly worried by this. McCandless's work has admirably illustrated that the conspiracy theory of illegal confinement does not stand up to investigation in most cases. ${ }^{12}$ Lord Shaftesbury, ${ }^{13}$ Chairman of the Lunacy Commission, always felt that there were few deliberately engineered confinements of the sane, and it was probably only the press that suggested otherwise. McCandless has demonstrated that most dubious confinements were the result of ignorance, incompetence, or carelessness. One exception to this rule was the certification of sane persons to help them escape the rigours of the criminal law, ${ }^{14}$ and more often than not this was inspired by motives of humanity to prevent a sentence of capital punishment being carried out. ${ }^{15}$

It was not these cases which worried civil libertarians, but those that illustrated the incompetence of medical practitioners as diagnosticians. Many doctors relied too heavily on subjectively determined symptoms when deciding whether or not to certify. ${ }^{16}$ The cases cited by McCandless show that evidence of mad behaviour given in

\footnotetext{
${ }^{9}$ M. MacDonald, Mystical Bedlam: madness, anxiety, and healing in seventeenth-century England, Cambridge University Press, 1981, passim.

${ }^{10}$ For a description of this process see D. J. Mellett, The prerogative of asylumdom, New York, Garland Press, 1983, introduction and pp. 187-210. Also, A. Scull, Museums of madness: the social organisation of insanity in nineteenth-century England, London, Allen Lane, 1979, ch. 5.

${ }^{11} 14 \mathrm{Geo}$ III c49 s27. The orders for confinement were only signed by one medical man, but the penalty on the madhouse owner for receiving a patient without this order was $£ 100$. Under sI, the penalty for detaining more than one patient without a licence was $£ 500$.

${ }_{12}$ P. McCandless, 'Insanity and society: a study of the English lunacy reform movement 1815-1870', PhD thesis, University of Wisconsin, 1974. Also idem., op. cit., note 6 above.

${ }^{13}$ Anthony Ashley Cooper, 7th earl of Shaftesbury (1801-85), chairman of the Metropolitan Lunacy Commission 1833-45 and of the Lunacy Commission 1845-85; commissioner on the Board of Health, 1848-54. See DNB; G. B. A. M. Finlayson, The seventh earl of Shaftesbury, London, Eyre Methuen, 1981.

${ }^{14}$ For a good example see PRO/HO45/OS/5521 - the case of the Rev. Edmund Holmes, member of a noted county family in Norfolk, who was certified to prevent his prosecution for the attempted violation of a twelve-year-old girl.

${ }^{15}$ For contemporary concern with this issue, see C. M. Burnett, Crime and insanity: their causes, connexion and consequences, London, 1852. Also, R. Smith, Trial by medicine: insanity and responsibility in Victorian trials, Edinburgh University Press, 1981, pp. 21-22.

${ }_{16}$ Although the 1845 Care and Treatment of Lunatics Act laid down certain inquiries which should be made on admission, there was no equivalent of the modern mental state examination. For examples of subjectively determined symptoms, see McCandless, op. cit., note 12 above, pp. 166-203. PRO/HO44/31 letter from Perceval to the Home Secretary, Lord Normanby, 5 April 1840. Perceval remarked of doctors, "there is usually much presumption and much false reasoning, craftily blended with unquestionable truths, in their statements."
} 


\section{N. Hervey}

testimony before the Commissions de lunatico ${ }^{17}$ often confounded immorality, eccentricity, and other non-conformist behaviour, with insanity. These opinions were sometimes rejected by lay juries, which undermined medical credibility; the unedifying sight of medical witnesses giving diametrically opposed evidence as to a person's mental state further reduced public confidence. It was for this reason that libertarians argued that unless a person was obviously a danger to himself or others, he should not be confined. However, the medical profession wished to establish their position as sole arbiters of normalcy in this process, and many doctors unwisely claimed special ability in detecting the fine shades between sanity and madness.

This claim assumed prominence, as Roger Smith has demonstrated, ${ }^{18}$ when medical testimony was employed in trials of the criminally insane. Here, conflict between medical and legal discourses centred, not only on the existence of insanity, but on whether a lunatic could be responsible for his actions. There was widespread concern that alienists, with their physicalist and hereditarian assumptions about aetiology, were creating the impression that individuals could not be held responsible for seriously violent or socially unacceptable behaviour, once the disease of insanity had set in. Clearly, this perspective, expressed through the insanity defence, undermined the concept of responsibility and posed a threat to the retributive and moral functions of the law. Jurists attacked the plea as the first step on a slippery slope to moral anarchy. Civil libertarians were not particularly interested in the insanity defence, but fervently believed in a much greater degree of self-determination and responsibility for the insane. In 1851, they were full of praise for the Lunacy Commission when it persuaded an appeal court to accept the testimony of lunatics in murder trials. ${ }^{19}$ Their fear was that the increased use of asylum detention for lunatics was gradually eroding their rights within the law. There is not room here to enter the debate on the sudden "visibility" of insanity in the late eighteenth century, but contemporaries did perceive a problem in the growing number of insane,${ }^{20}$ and the asylum appeared to provide a solution. Expansion of the county asylum system has been represented as part of a wider drive to incarcerate the poor and disadvantaged. ${ }^{21}$ It certainly offered opportunities for medical superintendents to consolidate their position and for the

${ }^{17}$ See pp. $265-266$ for a description.

${ }^{18} \mathrm{Smith}$, op. cit., note 15 above. Civil libertarians were in a quandary with the insanity defence, as they generally argued for a greater degree of responsibility for the insane. There is no evidence that they ever took much interest in the insanity defence, but they were involved in campaigning to improve the conditions of criminal lunatics once confined. See footnote 170 below.

${ }^{19}$ Commissioners in Lunacy, Sixth report, pp. 17-18. The prosecution of attendant Samuel Hill was completed when Lord Justice Campbell agreed to accept the evidence of a patient, Richard Donelly. Campbell argued that, "the proper test must always be, does the lunatic understand what he is saying, and does he understand the obligation of an oath?"

${ }^{20}$ Richard Powell, Observations on the comparative prevalence of insanity at different periods, London, Woodfall, 1813; Sir Andrew Halliday, $A$ letter to Lord Robert Seymour: with a report on the number of lunatics in England and Wales, London, Underwood, 1829. The problem continued to puzzle commentators into the mid-nineteenth century. See John Thurnam, Observations and essays on the statistics of insanity, London, Simpkin Marshall, 1845; and W. A. F. Browne, What asylums were, are, and ought to be. Edinburgh, 1837, pp. 50-55.

${ }^{21}$ Scull, op. cit., note 10 above; and Mellett, op. cit., note 10 above. Many contemporaries identified this process too, and not just libertarians. See the Annual Report of Kent County Asylum Superintendent, J. Huxley, in 1861/2, p. 20. 
Lunacy Commission to develop. Both had a vested interest in more asylums, and both undermined traditional forms of care within the family by stressing the need for early removal from the home environment. ${ }^{22}$ This trend worried libertarians, who disliked the ease with which behaviour was being defined as sufficiently disturbed to justify detention, and questioned the benign view reformers had of the new asylums.

In the past two decades, a new tradition in psychiatric history has undermined previous accounts of a progressive scientific objectivity and humanitarianism in treatment. Foucault ${ }^{23}$ questioned the benevolent light in which Tuke's moral treatment at York had been cast, and subsequently, Rothman and Scull have explored the element of social control inherent in the establishment of asylums, identification of patients, and their treatment. ${ }^{24}$ These studies suggest that we may need to look more closely at how patients' freedoms were compromised as a new system of care evolved.

It is evident that by 1850 , despite continuing fears of illegal confinement, most Victorians supported involuntary detention, fearing the consequences of allowing lunatics to remain at large. The problem remained how to feel secure that the right people were being confined, and it was not clear whether the medical profession could be entrusted with this decision. Wilkie Collins, Henry Cockton, and Charles Reade, heirs to Defoe and Smollett, ${ }^{25}$ all fed public uncertainty with their novels, drawing on the well-publicized periodic lunacy scares. ${ }^{26}$ They cast doubt on the motives of asylum proprietors and highlighted the way doctors made arrangements to supply particular asylums with patients. ${ }^{27}$ Only stringent certification procedures, better qualified doctors, and regular asylum visitation could redress abuses in the system, but their preoccupation with wrongful confinement prevented a more sophisticated analysis of the way mad people were perceived and treated.

Select committees before $1827,{ }^{28}$ which uncovered significant abuse of patients, did

22 R. G. Hill, A lecture on the management of lunatic asylums, London, 1839, pp. 4-5; Commissioners in Lunacy, Further report, 1847, pp. 118-119.

${ }^{23}$ Michel Foucault, Madness and civilization, London, Tavistock, 1979, ch. 9. Foucault's suggestion that mechanical restraint had merely been replaced with more terrifying internal restraints that patients were asked to impose on themselves through the internalization of society's values, is similar to the feeling many libertarians expressed.

${ }^{24}$ Scull, op. cit., note 10 above; and David Rothman, The discovery of the asylum, Boston, Mass., Little Brown, 1971. Rothman's critique of Jacksonian society and attempt to separate the American experience from Europe's, are less convincing. See A. Scull, 'The discovery of the asylum revisited: lunacy reform in the new American republic', in Scull (editor), op. cit., note 6 above. The idea that causal links between the increasing "civilization" of society and the growth of insanity remained popular amongst alienists in America after its disappearance in Britain, is untrue. Civil libertarians including the ALFS, certainly posited a link between the two in nineteenth-century England.

${ }^{25}$ Wilkie Collins, The woman in white, London, 1860; Henry Cockton, Valentine Fox, London, 1840; Charles Reade, Hard cash, London, Routledge, 1905 (1st ed., 1863).

${ }^{26}$ Reade resented suggestions that he merely relied on sensationalized newspaper accounts for his novel. In an article to the Daily News, 23 October 1863, he stated that he relied "mainly on the private cases, which a large correspondence with strangers, and searching inquiry amongst my acquaintances have revealed to me ... . to show you how strong I am, I do not rely at all on disputable cases like Nottidge, Ruck and Leech." From the range of cases he mentions in this article and a subsequent one to the Pall Mall Gazette (17 January 1870), he had evidently gathered a wide range of material.

${ }^{27}$ See the case of George Boddington, MD, in PRO/HO45/0S/6686, mentioned in McCandless, op. cit., note 6 above. Also Br. med. J., 1857, i: 52, for an example of advertising for this kind of arrangement.

${ }^{28}$ In 1807 and $1815 / 16$. 


\section{N. Hervey}

not lead to controls, ${ }^{29}$ and safeguards instituted in 1828 were woefully inadequate. The Metropolitan Lunacy Commission provided a more efficient inspectorate in London, but elsewhere local magistrates continued to be responsible for licensing and visitation. Certificates were at last introduced for paupers, and those for private patients improved, but in practice many of the new provisions proved worthless. ${ }^{30}$ Madhouse owners continued to certify their own patients, ${ }^{31}$ and the process for discharging those held illegally was unnecessarily cumbersome. ${ }^{32}$ In the provinces, justices sometimes failed to visit asylums at all, or made only the most perfunctory inspections. Reforms were clearly needed, and a full-time Lunacy Commission was set up in 1845, under the Care and Treatment of Lunatics Act. This will be discussed later, but it is important to acknowledge here the failure of previous administrative measures to protect patients' rights. Civil libertarians certainly wished to point out loopholes in the law that could lead to wrongful confinement, but increasingly they became concerned at the way mental illness was perceived in Victorian society, and the implication that custodial care was the only really appropriate way to treat the insane. We must now turn to a closer examination of their contribution.

\section{"A Nucleus Attended by a Splendid Train of Supporters"33-The Personnel, Objectives ANd Philosophy of The Society}

In 1838, Richard Paternoster, a former clerk in the Madras Civil Service was released from Dr Finch's madhouse at Kensington after a confinement of forty-one days. ${ }^{34}$ His seizure and detention had followed disagreement with his father over money. On discharge, he advertised in The Times for fellow sufferers to join him in a campaign to redress abuses in the madhouse system. He was joined by four men initially, the most important of whom was John Thomas Perceval the fifth son of the assassinated prime minister, and younger brother of Spencer Perceval, the

\footnotetext{
${ }^{29}$ A series of bills were put forward between 1813 and 1819 , which are worthy of closer examination on the lines O. MacDonagh employed in his study of the Passenger Acts. The clauses proposed included the tightening up of medical qualifications for those signing certificates and the appointment of specially approved doctors for the purpose. Many other ideas were lost, only to be laboriously rediscovered by later administrators, or form part of the ALFS's campaign. PP 1813-14 (204), 1, 411, p. 16 and (267), 1, 439, Clause D.

${ }^{30}$ A non-pauper could only be admitted on the certificates of two doctors, who had visited him separately within fourteen days of each other. A pauper could be admitted on the order of two JPs, or of an overseer and the officiating clergyman of the parish, accompanied in either case by a certificate signed by a doctor. The Act also prohibited doctors certifying patients for any asylum in which they had a financial interest or of which they were regular medical attendants. 9 Geo IV, c4I, ss XXX and XXXI.

${ }^{31}$ In Kent, a county where the magistrates did visit, admission records for West Malling Madhouse illustrate this. Between 1828 and 1834, George Perfect, visiting medical officer, who had a financial interest in the asylum, signed four certificates of admission. Kent CRO/QALp/5.

329 Geo IV c41 s37 dictated that twenty-one days elapse between each of three visits to the patient before he could be discharged. As the magistrates only inspected four times a year, this could mean at least $4 \frac{1}{2}$ months' confinement before discharge if a patient was admitted soon after their visit.

${ }^{33}$ The Times, 16 April 1846.

34 Richard Paternoster, described as "an uncorrected heartless ruffian ... low in mind and coarse in language" by Shaftesbury, was only discharged by the Metropolitan Lunacy Commissioners on a split vote of 6 to 4. (Diaries of the 7th earl of Shaftesbury, National Register of Archives, SHA/PD2, 3 October 1838.) Paternoster subsequently wrote The madhouse system, London, 1841. For further details see Parry-Jones, op. cit., note 5 above.
} 
Metropolitan Lunacy Commissioner. ${ }^{35}$ Both John and Spencer adopted their father's evangelical fervour, and in 1830 joined the Irvingite Church. ${ }^{36}$ The following year, John became involved in the miracles at Row, where he witnessed talking in tongues and other strange phenomena. Even at this stage, fellow community members felt his behaviour was erratic and unpredictable. In December 1831, he went to Dublin where he developed an acute psychotic illness. Spencer arranged his return from Ireland and placed him at Brislington House, a private asylum in Bristol, run by Edward Long Fox. It had been purpose-built as a madhouse and was known as one of the foremost institutions of its kind. Dr Fox, a Quaker, had even been invited to treat George III, such was his reputation, and yet Perceval had hardly a good word to say about the asylum. ${ }^{37}$ In 1832, he was moved to Ticehurst, in Sussex, another private asylum, which enjoyed an even higher reputation, treating many members of the aristocracy. He remained there until his discharge in $1834 .^{38}$

Perceval claimed that his care in these asylums, especially at the former, had been barbarous. He alleged that he was forced to use a clyster in his brother's presence, was kept in a strait-waistcoat, was hit around the head, pulled by the nose, and had his hair cut in a ludicrous fashion. ${ }^{39}$ Both Paternoster and Perceval published accounts of their experiences. These were to prove a handicap to the ALFS because they alienated the medical profession. The main thrust of Perceval's argument was that Fox had not treated him as a gentleman or an individual. He was barred from any discussion about his treatment, and when he challenged Fox's methods he was punished with solitary confinement, the strait-jacket, or a cold bath. Clearly, Perceval had been very disturbed on admission, but this does not invalidate his criticisms, which illustrate the lack of dialogue between doctor and patient. He and Paternoster also upset the Metropolitan Lunacy Commission and local magistrates by exposing frailties in the inspectorial system. In 1840, Perceval wrote that magistrates "know what gentlemanly feeling is, and the wants of a gentleman, and yet, year after year they visit the asylums in which patients are, and see the painfully indelicate situation in which they are placed, and yet do not once take pains to put themselves in the patient's place and ask themselves how they would like to be treated even for a week... in the same

\footnotetext{
${ }^{35}$ See Richard Hunter and Ida Macalpine, 'John Thomas Perceval (1803-76), patient and reformer', Med. Hist., 1962, 6: 22-26. Perceval was author of: $A$ narrative of the treatment experienced by a gentleman during a state of mental derangement, 2 vols., London, Effingham Wilson, 1838 and 1840; Letters to Sir James Graham upon the reform of the law affecting the treatment of persons alleged to be of unsound mind, London, 1846; A letter to the Secretary of State for the Home Department upon the unjust and pettifogging conduct of the Metropolitan Commissioners in Lunacy in the case of a gentleman lately under their surveillance, London, 1844.

${ }^{36}$ The Catholic Apostolic Church was founded in the late 1820s, and inspired by the teachings of Edward Irving (1792-1834). It developed from a revivalist circle which gathered round Henry Drummond (1786-1860), who built a church on his estate at Surrey. Drummond was a keen supporter of the ALFS.

${ }^{37}$ Edward Long Fox 1761-1835. MD Edinburgh 1808, MD Oxford 1835. Physician to Bristol Royal Infirmary 1816-43; 1792-1804 proprietor of Cleeve Hill Madhouse; 1804-35 proprietor of Brislington House. For invitation to treat George III, see Bristol Evening Post, 23 March 1960, p. 8. Also Parry-Jones, op. cit., note 2 above, chs. 3 and 4 .

38 For details see ibid. Also, C. Mackenzie, 'Social factors in the admission, discharge and continuing stay of patients at Ticehurst Asylum, 1845-1917', in W. F. Bynum, R. Porter, and M. Shepherd (editors), The anatomy of madness: essays in the history of psychiatry, 2 vols., London, Tavistock, 1985.

${ }^{39}$ Perceval (1838), op. cit., note 35 above, pp. 12-22. Perceval also claimed he was denied paper for the privy, and saw keepers half-strangling another patient.
} 


\section{N. Hervey}

manner." 40 Many considered that Perceval had broken ranks in thus exposing his own class, and Lord Raglan remarked that it was evident he did not care what he said. Shaftesbury, a Harrow contemporary of Perceval's, also felt that he was telling tales out of school and remained reluctant publicly to acknowledge his existence thereafter. $^{41}$

Paternoster and Perceval were joined in 1839 by William Bailey, an inventor who had spent five years in madhouses, ${ }^{42}$ Captain Richard Saumarez, $\mathrm{RN},{ }^{43}$ who had two insane brothers under the court of Chancery, and Dr John Parkin, ${ }^{44}$ another ex-patient. This group petitioned the Home Secretary, Lord John Russell, to discover what measures the government were drawing up to reform the existing laws. ${ }^{45}$ Having received the reply that he could offer them no information on the subject, they began their campaign to secure a Select Committee. Successive Home Secretaries were bombarded with advice, petitions, and legislative proposals, ${ }^{46}$ and the help of radical MP Thomas Wakley ${ }^{47}$ was enlisted. In 1842 , they provided the only challenge to Granville Somerset's bill widening the scope of the Lunacy Commission, arguing that it was asking an inefficient body to report on its own proceedings. They suggested the Commission was bound to give a favourable account of its own efforts, and recommended an independent inquiry. By 1845 , with the virtual reappointment of the old Commission, it had become clear that the group required a greater degree of organization. A meeting was arranged for 7 July 1845 , at which a permanent,

${ }^{40}$ Ibid., p. 6.

${ }^{41}$ PRO/MEPOL3/20. Raglan to R. Mayne, Commissioner of Police, 44 May 1850. Perceval had admitted as much in 1846 in a letter to Peel, stating that he had expressed his opinions "without respect to persons or to my future prospects-and this is my only merit." (British Museum, Add.MSS, Peel Papers, 40,582, f 91.) He continued the school allusion in 1861, remarking of Shaftesbury's Commission, which allowed the withholding of patients' correspondence: "I feel so indignant at this under the plausible superintendence of Lord Shaftesbury-that I sometimes can scarcely believe that he is the man that was educated with us at Harrow - that gentlemanly and public spirited school." (PRO/HO45/OS/7102, Perceval to George Clive, 9 May 1861.)

42 For an account of William Bailey, see his petition to the Commons, HC, Supplement to the Votes 1845 , Vol. 2, pp. 1144-1145. Also Perceval (1846), op. cit., note 35 above, letter concerning a Mr B[ailey]. Bailey was also an overseer in the parish of St Giles-in-the-Fields and as such was involved in care of the pauper insane.

${ }^{43}$ Richard Saumarez 1791-1866. (Son of Richard 1746-1835, the surgeon and prolific polemical writer on medical education and the duties of medical corporations.) Town Councillor at Bath; guardian of St Luke's, Chelsea; FRS. Author: An address on the laws of lunacy for the consideration of the legislature, London, 1854; The laws of lunacy, and their crimes, as they affect all classes of society, London, 1859.

44 John Parkin MRCSE 1822, Fellow Royal Medical and Chirurgical Society, London; surgeon in the East India Co., surgeon to the General Annuity and Endowment Association, fellow member of Perceval's at the Parthenon Club, Regent Street. Author of papers and books on tropical disease and the state of the profession.

${ }^{45}$ PRO/HO44/33, letter to Russell, 30 January 1839. In fact, Perceval had been in trouble with the Home Office before this for literature distribution calculated to inflame the lower orders. (HO40/40, 20 June 1838.)

${ }^{46}$ HO 44/49, Perceval to Normanby 5 April 1840; BM, Add.MSS, Peel, 40426, f243, 8 May 1839, Perceval to Peel; and 40523, f 397, 26 January 1843, Saumarez to Peel. In 1839, there were petitions from Perceval, Saumarez, and the Parish of St Luke's, Chelsea. Perceval and Bailey petitioned in 1842, and in 1845, there were seventeen petitions inspired by this group.

47 Thomas Wakley (1795-1862) MRCS 1823. Founded the Lancet in 1823. MP Finsbury 1823-62. Middlesex Coroner 1839-62. Wakley had a particular interest in this subject, because he had a nephew, Mr Townsend, who had been confined at Southall Park asylum. (Diaries of Alexander Morison, Royal College of Physicians of Edinburgh, 24 April 1849.) 
non-sectarian, and apolitical organization was established. The objectives that emerged during the first year were: to campaign for changes in the lunacy laws, which would reduce the likelihood of illegal incarceration and improve the condition of asylums; to offer help to discharged patients, and to convert the public to an enlarged view of Christian duties and sympathies. Most important of all, the Society announced it would henceforth exist to forward any matters the Commission might overlook. ${ }^{48}$ This superior attitude did not endear the Society to the public, and its extensive brief was undermined by strategical errors. First, by making the unfortunate antecedents of several of its members a matter for pride, rather than distaste, the Society reduced its credibility as a rational force. In addition, its fearless exposure of upper-class sensibilities regarding the privacy of this subject intimidated the very groups that normally patronized charitable organizations. It also became a matter of principle that the stigma attached to ex-asylum inmates should never be a barrier to normal integration. Perhaps the situation demanded the adoption of this more extreme position but the Society's hard-line approach was compounded by a further error of judgement: alignment with radical political circles, which reduced its support both in and out of parliament. Finally, its endorsement of localist views, such as those held by Toulmin Smith, antagonized the Lunacy Commission, which was committed to setting up a central repository of expertise in this field. ${ }^{49}$ Thus the Society's ends were often hampered, if not defeated, by its means, although this explanation for its failures does not do justice to the opposition generated by the novelty of its proposals.

The general philosophy of the ALFS stemmed from traditional appeals to Anglo-Saxon law, Magna Carta, the writings of Edward Coke, and more controversially, Paineite concerns with the right of individuals to certain inalienable freedoms within the welfare of society as a whole. ${ }^{50}$ Each patient should have a voice in his confinement and care, and access to legal representation. Perceval led the way, attacking the new forms of moral treatment as an imposition of society's values on the individual. In 1845, he remarked, "the glory of the modern system is repression by mildness and coaxing, and by solitary confinement." He expressed suspicion of the tranquility so frequently admired by the Commissioners in asylums, and suggested that patients were first crushed, "and then discharged to live a milk sop existence in

\footnotetext{
${ }^{48}$ In 1859, Perceval stated that the foundation of the Society was chiefly due to Mr Luke Hansard. An examination of the Hansard Papers suggests that Luke may have had a daughter or a daughter-in-law called Mary Ann who was mentally disturbed and boarded with a Mrs Aveling. (Hansard papers, Southampton University Library, Accts and MSS, LF 780 Uni/103.) The information about the ALFS's aims is taken from a pamphlet dated 1846. Several sources including Jones (op. cit., note 4 above) and Parry-Jones (op. cit., note 5 above) quote the Society as producing pamphlets in 1851 and 1858. Pamphlets for 1846 and 1849 have also been found to date. These and the pamphlet dated 1851 are to be found in the Forster MSS, Victoria and Albert Museum, Pamphlet Collection.

${ }^{49}$ Perceval (1846), op. cit., note 35 above, letter dated June 1844. Perceval wrote, "for my own part I do not approve of Commissions of this kind, for the administration of the laws of this country, more particularly where they interfere with the ordinary channels of government."

${ }_{50}$ PR0/H045/OS/7102 Perceval to George Clive, 2 May 1861, appeal to Magna Carta and the universal meaning of laws as found in Montesquieu. For comparison, see the petition of William Morgan to the House of Lords in 1847 (JHL, LXXXIX, 1847, p. 159). There is an interesting discussion of the appeal to traditional constitutional rights, especially in the context of opposition to central government, in William Lubenow, The politics of government growth: early Victorian attitudes toward state intervention, 1833-48, Devon, David \& Charles, 1971, passim.
} 


\section{N. Hervey}

society". 51 The ALFS adopted this stance too. Its first prize essay was offered for a treatise to illustrate ways in which the influence of role and conduct in society created "irritations of the Will in individuals". In 1846, the Society's initial report also reflected this preoccupation, referring to the public's condescending attitude and servile imitation of society's rules and orders, "being supposed to form and constitute them part of the sane world, entitled to sit in judgment." 52 These attitudes reflect the presence of a number of ex-patients within the Society. The Society believed that much mental illness stemmed from the disappointments and rejections of life, and questioned the medical wisdom that patients had to be isolated from their home associations, desiring practitioners to pay more attention to what the insane were saying. ${ }^{53}$ The Society was keen to combat the message of moral treatment, which, in implying that the mad needed re-education, perpetuated the status they had often been afforded in the past as a protective device, namely, that of children. ${ }^{54}$ All its proposals bespeak the desire that, whenever possible, lunatics should be treated as adults capable of making decisions for themselves. Perceval certainly believed that more rights of appeal should be built into detention procedures and felt patients were generally kept ill-informed of their legal position. In 1859 , he also suggested that they were rarely given the chance to exercise their will or judgement, which had a very material effect in impeding their recovery. 55

The adherents acquired in 1845 generally endorsed the above beliefs, and did not therefore provide a more socially acceptable membership. It is not clear how many ordinary members the Society had, ${ }^{56}$ but there were eighteen vice-presidents, and seventeen directors, many of whom took an active role. Several of these were noted for the singularity of their views. The MPs Thomas Wakley, Thomas Duncombe, and William Sharman Crawford might have received support for their opposition to the New Poor Law ${ }^{57}$ and other centralist government agencies, but their radical politics and involvement with the Chartist movement helped brand the Society as "unsafe". Despite the apolitical tag and an even complement of whig/radical and tory MPs, ${ }^{58}$ the

\footnotetext{
51 Perceval (1846), op. cit., note 35 above, 1 August 1845; Cf. Foucault, op. cit., note 23 pp. 241-278.

52 ALFS, 1st report, Origin, progress and expenditure of the Society, with its laws and regulations, London, W. McDowell, 1846 , pp. $1-4$.

${ }^{53}$ For removal from home, see E. J. Seymour, Thoughts on the nature and treatment of several severe diseases of the human body, London, Longman Green, 1847, pp. 170-220. Seymour opposed this, but made it clear it was axiomatic amongst his contemporaries. For discussion, see Scull, op. cit., note 10 above, pp. 90-102. Perceval, (1840), op. cit., note 35 above, pp. XVIII.

${ }^{54}$ See N. Walker, Crime and insanity in England, Edinburgh University Press, $1968 \mathrm{ch}$. 2; and Smith, op. cit., note 15 above, pp. 70-74, for discussion of the exemption of madmen from the consequences of the criminal law, which was linked to the age of discretion in children.

55 Report of the Select Committee on Lunatics, PP 1859, Sess. 2, VII, p. 20.

${ }^{56}$ It is true that the Society was not well supported, but those who did help were often influential. In addition to their own MPs, the ALFS received regular assistance from the following liberal-minded parliamentarians: Lord Dudley Stuart (Marylebone), Charles Lushington (Westminster), Benjamin Hawes (Westminster), Bernal Osborne (Dover), Lord Duncan (Bath), Sir William Tite (Bath), Mr Mitchell (Bodmin), and Henry Drummond (Surrey). The Society probably had no more than 50-60 members.

57 A number of members, including Perceval, Saumarez, and Bailey who were local Poor Law officials, shared this perspective. Perceval wrote to several MPs about the iniquities of separating man and wife in the workhouse in contempt of the solemn rites of the marriage ceremony, and the Society extended this to a condemnation of separation within asylums. (BM, Peel Papers, Add.MSS, 40,558, f 450, Perceval to Peel, 31 January 1835.)

58 About eight of each.
} 


\section{The Alleged Lunatics' Friend Society}

greater commitment of the former group gave the Society a decidedly liberal character. In fact, the conservative element tended to become influenced by its freethinking ideology and was criticized for it. In February 1859, the Morning Post reported a meeting chaired by the MP Benjamin Bond Cabbell, at which several ex-patients from Hanwell, Colney Hatch, and Surrey County Asylums made serious allegations about abuses in those institutions. The Post added, "Mr Cabbell will not forward the cause he professes to advocate by listening without protest, as chairman, to such evidently false accusations." 59 Similarly, Cabbell and R. A. Christopher ${ }^{60}$ presented bills in Parliament full of major departures from traditional policy, which they might have avoided in considering other subjects.

However, the new members did provide useful links in many spheres that involved the insane, not least Cabbell and Christopher at Bethlem. ${ }^{61}$ These links will be examined later, but it is clear that the different views members brought with them were potentially divisive. The most important new member in this respect was Gilbert Bolden, ${ }^{62}$ a lawyer who drew together disparate elements within the Society. He eschewed the extremists and those pursuing personal interests, and attempted to obtain a common set of demands which would have a wider appeal. For the Lunacy Commission he was, potentially, the most dangerous member of the Society, as it proved less easy to dismiss him as a firebrand, and he was not identifiable for previous activities. But Bolden had his hands full as the initial group of campaigners expanded.

During the early years, Perceval was still adjusting to personal psychiatric problems and his constant references to religion were deprecated by Saumarez, who felt they "damaged the cause". But Perceval was unrepentent, believing that the Church had abandoned this issue owing to its social delicacy. ${ }^{63} \mathrm{He}$ continued to advocate greater clerical involvement in the care of the insane, and his views were in time accepted to some degree by the others. Disagreement also emerged over an issue generally taken as axiomatic to the Society's philosophy, the abolition of private asylums and lodgings. Despite his own experience, Perceval remained true to his background and believed that gentlemen should be provided with care commensurate with their station in life, private lodgings with personal attendants. ${ }^{64}$ Barring this, moral treatment and

59 Morning Post, 3 February 1859.

${ }^{60}$ Benjamin Bond Cabbell 1781-1874. MP St Albans 1846-7, Boston, Lincolnshire 1847-57; FRS 1837.

Robert Adam Christopher 1804-77. MP City of Edinburgh 1831-2, North Lincolnshire 1837-57; FRS 1833; PC 1852.

${ }^{61}$ Cabbell was also a governor of St Luke's Hospital. Drummond was a Surrey County Asylum Visitor. Not all the new adherents were an asset, however. Viscount Lake 1781-1848, for instance, had been dismissed from the Navy for gross cruelty. He did not appear to take any part in the Society's activities. The ALFS did try to recruit members who would lend real weight to their campaign. (See Royal Society Collection: Sir John Lubbock's Papers, LUB/A/213, letter from Luke Hansard to Lubbock, 19 August 1845.)

${ }^{62}$ Gilbert Bolden 1801-64. A London solicitor, Bolden was admitted to the Roll of Michaelmas 1834. Initially, he practised in Bloomsbury, and in 1841, moved to Westminster. In 1844, his address was suddenly given as Country Attorney, Walton, Lancashire, and it is just possible that he was an inmate of the asylum there at this time. Subsequently, his address was at Craven Street, home of the ALFS.

${ }^{63}$ PRO H045/0S/7102, Perceval to the Home Office in 1861 concerning proposed lunacy legislation. Letter to George Clive, 4 April 1861.

${ }^{64}$ PP 1859, Sess. 2, VII, p. 43. For a description of the system of single lodgings, see N. Hervey, 'A slavish bowing down: the Lunacy Commission and the psychiatric profession 1845-60', in Bynum et al. (editors), op. cit., note 38 above. 


\section{N. Hervey}

non-restraint were best when modified and perfected in private asylums, rather than large public institutions. This ran against the current of opinion in the Society. Perceval however, saw clearly the weakness inherent in Shaftesbury's budding County Asylums. He felt small private asylums might be improved by placing them in government hands, but remarked of public asylums as early as 1843 , "I do not think it likely a system carried out by public officers will improve so readily as one carried out by private hands ... I do not think a public system will be so easily impugned or corrected as a private one, should abuses creep into it." 65

As other members of the society came into contact with the public sector, they too adopted Perceval's views of the need to perpetuate and improve the private sector. The Society also spent a lot of time representing pauper interests, sometimes through specific cases, ${ }^{66}$ but more often through the global rights it advocated. The difficulty arose from the fact that these rights were located at the interface of medical professionalism, government growth, and individual freedoms. The Lunacy Commission, although ceding a large measure of control in county asylums to the superintendents, was anxious to retain an ultimate veto on medical activities. This should have given it some sympathy with the Society's views, but whilst it was true that individual Commissioners supported aspects of the Society's programme, ${ }^{67}$ the Board was wary of alienating the medical profession by curbing its powers in favour of patients' rights. Some of the ALFS's ideas, such as termination of the medical officer's power to detain pauper lunatics in a workhouse without any legal documentation, were taken up by the Board, but these were often issues which caused conflict between doctors and other members of the Society. The former comprised a small, but influential group, who were nearly all involved in expanding the role of their profession. Some concession had to be made to their opinion. ${ }^{68}$ It was not so much these internal differences that handicapped the Society, as the determined opposition to their views from various vested interests, and we must now turn to an examination of their strategy and achievements.

\footnotetext{
${ }^{65}$ Perceval, (1846), op. cit., note 35 above, letter dated 25 January 1843 . See also letter dated 31 January 1843 , "I am convinced that the collecting of lunatic patients together is a necessity to be deprecated, rather than a principle to be admitted."

${ }^{66}$ The Society worked on many cases in county asylums and workhouses, appointing their own visitors to investigate charges. It supported the foundation of charitable funds like the Queen Adelaide's at Hanwell (to which both Cabbell and Saumarez contributed) and it provided ex-pauper patients with references for jobs. ALFS, 1st annual report, pp. 1-2.

${ }^{67}$ Samuel Gaskell (1807-96) supported the idea of voluntary admissions (J. Ment. Sci., 1860, 6: 321-327), as did Bryan Waller Procter (1797-1874). See V \& A, Forster MSS, 48 E 32, Procter to Forster 5 September 1869. W. G. Campbell (1810-81) also agreed with many of the Society's proposals, notably the idea that a relative signing the order for an admission should have seen the patient within the recent past. (PP, 1859, Sess 2, VII, p. 62).

68 They included Wakley; George Alfred Walker, a notable writer and campaigner on the Metropolitan Burials issue; Robert Barnes, an authority on the diseases of women and children, and translator of Baillarger's Lectures on mental diseases; Henry Walker, who petitioned Parliament in 1845 about the lunacy bills; Thomas Dickson, Superintendent of Manchester Royal Lunatic Hospital, Cheadle, Cheshire, and author of Observations on the importance of establishing public hospitals for the insane of the middle classes, 1852; John Parkin, see footnote 44 above. Also used by the Society were Dr Wm. Buchanan MD (retired) of Cheshunt, Herts, and a Dr Pearce.
} 


\section{(I) Parliament and Government}

I do not despair of opening Mr George Lewis's [Home Secretary] mind to the justice and commonsense reasonableness of some of my views-more particularly if, as in Lord Shaftesbury's conduct with regard to the private lunatic system, I show the inconsistency between his opinions and projects. (J. T. Perceval ${ }^{69}$ )

From 1845 to 1863 , Parliament and governments were bombarded with literature by the ALFS. ${ }^{70}$ Most was directed at the Home Secretary, who, it was hoped, would use the information as a means of putting pressure upon the Lunacy Commission. In 1859, Perceval remarked, "what has compelled me always to load Honorable Secretaries of State with long letters? It is because ... if I write to the Commissioners, I have no security that I shall have an upright decision." 71 Inevitably, prolonged exposure to the Society's beliefs proved effective, and gradually, many of its ideas were plagiarized by the Board. True to a meanness of spirit the Commissioners often displayed, and an impoverished sense of their own security, they were afraid to acknowledge the origin of these contributions, and tacitly accepted credit for them. This is amply illustrated by the 1845 Care and Treatment of Lunatics Act. The ALFS strenuously opposed this measure through its MPs Wakley, Duncombe, and Crawford. In particular, it objected to another Commission which would invest increased power in a central authority at the expense of local jurisdictions. ${ }^{72}$ Duncombe maintained the new Board would not be sufficiently impartial to give patients a fair hearing, and referred to it as a body, "hateful and foreign to the Constitution", ${ }^{73}$ adding that he would divide the Commons at every opportunity.

Shaftesbury feared Duncombe's ability to do so, and angrily believed that Duncombe had given the subject little thought. His own carefully prepared case does not seem to have had much appeal either. On 22 July, he wrote, "very few aided me-none of the pious party of the House. I have received from them nothing but empty commendation. Strange that such a man as Mr Duncombe omni corruptus vitio should so triumph." The following day, he capitulated to ensure the safety of his measures, and made a private accommodation with Duncombe. ${ }^{74}$ The importance of the clauses Duncombe then obtained for the Society has never been fully appreciated, nor have their origins been acknowledged. ${ }^{75}$ They include some of the most important safeguards for patients in the new legislation. Amongst them are clauses insisting that

\footnotetext{
${ }^{69}$ PRO/HO45/0S/7102 Perceval to Clive 55 April 1861.

${ }^{70}$ The Society submitted petitions in 1846, 1847, 1848, 1849, and 1852.

71 PP, 1859, Sess 2, VII, p. 46.

72 Duncombe and Crawford also opposed retiring pensions for Commissioners and suggested a reduction in their proposed salaries. The language used by these men and other members of the ALFS reflects many of the preoccupations of Joshua Toulmin Smith (1816-69), the lawyer, phrenologist, and localist champion. See Government by commission, illegal and pernicious: the nature and effects of all commissions of inquiry ... and the importance of local self-government, London, Sweet. 1849.

${ }_{73}$ Hansard, HC, 3S, LXXXII, 16 July 1845, pp. 14-15. Also, JHC, vol. C, 2, 15, and 16 July 1845 for split votes.

${ }^{74}$ Shaftesbury diaries, loc. cit., note 34 above, SHA/PD/4, 5, 22, and 23 July 1845.

${ }^{75}$ Francis Offley Martin, the Charity Commissioner, made some acknowledgment, An account of Bethlem Hospital: abridged from the report of the late Charity Commissioners, London, William Pickering, 1853. The book was dedicated to Duncombe for his opposition to the exemption of Bethlem from the 1845 Act, and Martin sought to obtain the continuing support of the radical Metropolitan MPs to secure further reforms.
} 


\section{N. Hervey}

licensees of private asylums should reside on the premises, and that doctors should state the facts concerning patients' illnesses on their certificates. Duncombe was unable to obtain a coroner's inquest on all persons dying in asylums, ${ }^{76}$ as occurred in gaols, but did secure a stipulation that medical attendants should report all deaths to the local Registrar within forty-eight hours. Other major rights were also procured. In future, abused or neglected patients could get a copy of their orders and certificates, and the Home Secretary could direct the prosecution of those illegally confining or maltreating patients. $^{77}$

The very need for the Society to promote these clauses suggests that the legislation of 1845 was rushed and inadequate. Shaftesbury also rejected several good proposals that the Commission later legislated for, and others that could usefully have been included. ${ }^{78}$ The Society's contribution illustrates that it had already considered the need to legislate for an improved quality of asylum owner, and, in time, it became concerned with all aspects of patient care. Draft bills were presented to Parliament in $1847,1848,1851$, and 1853 by its MPs, and all were carefully studied by the Home Office before being forwarded to the Commission. These bills were a curious mixture of outlandish and sound proposals, a few of which were adopted. In 1853, for instance, it was mooted that bishops should be entitled to attend board meetings of the Commissioners or Visiting Justices and vote as ex-officio members. Clearly, this could never have been endorsed, constituting as it did, a serious abrogation of official powers. ${ }^{79}$ It was this kind of ludicrous suggestion that fed the Society's opponents with ammunition, and distracted attention from more practical ideas.

The ALFS also made a number of valuable recommendations in 1853, when new legislation was being prepared. It wanted clauses in the act relating to patients' legal rights displayed in the wards of every asylum, and proposed that routine medical reports record whether inmates denied the propriety of their detention. Other useful ideas included the following: that patients' property should have a seal placed on it the moment they were confined, only to be removed in their presence or an attorney's; that licences should only be granted to proprietors of integrity or celebrity in treatment of the insane, or those pioneering new advances; and that asylums where patients could reside voluntarily should be established as half-way houses between admission and discharge. ${ }^{80}$ Once again, only a few of the Society's ideas were adopted. It obtained an improvement in medical certificates, and also a clause that in cases of death, the registrar should report to the coroner when there was reasonable cause for suspicion. ${ }^{81}$

\footnotetext{
${ }^{76}$ This was always a major objective of the Society. It had, in fact, been proposed in 1828 , but was struck out of Gordon and Ashley's bill by the Lords.

778 and 9 Vict $\mathrm{cl00}$, ss $24,45,46,48,55,56,106$, and 105 . In view of the mental fragility of patients on discharge, his clause extending the time limits within which they could bring cases of illegal confinement to court was particularly useful.

${ }^{78}$ The protection of patients' property automatically once admitted, the establishment of half-way houses with voluntary confinement, written justification for a detention by the signer of an order of admission, and increased visitation. Perceval (1846), op. cit., note 35 above, letters V, VI, and VIII.

79 J. T. Perceval, Hints for the abolition of private lunatic asylums and for a reform of the laws respecting the seizure and confinements of persons alleged to be of unsound mind, London, 1853, p. 4. (Found in PRO/H045/0S/7102.)

${ }^{80}$ Ibid., pp. 1-4.

8116 and 17 Vict c96, ss 10 and 19.
} 
These gains seem meagre reward for the Society's campaign, but it had sown the seeds for a number of other changes by its preoccupation with the admission process and the rights of patients once incarcerated ${ }^{82}$ Its continuing persistence was finally rewarded in 1859 , when an ally, Mr Tite ${ }^{83}$ presented a petition to Parliament, which led to a Select Committee on Lunatics. Some historians have depicted this as the Society's greatest achievement, but the latter perceived it as a major disappointment. ${ }^{84}$ Taking advantage of a wave of hostility towards the lunacy laws aroused by three court cases, the Society had hoped to force the Home Secretary, S. H. Walpole, ${ }^{85}$ into wide-reaching changes. In 1862, Saumarez wrote to Walpole's successor, Sir George Grey, "you are perhaps not aware that the Hon. S. H. Walpole introduced the Bill of 1852-3 and was naturally jealous of its frightful working being exposed-and for this same reason he packed the 1859 Committee and was elected Chairman instead of $\mathrm{Mr}$ Tite who moved for the appointment of the Committee. As Chairman he prevented such evidence being adduced as would have exposed the abuses." ${ }^{86}$ Key witnesses Perceval wished to introduce were never called, most important of whom was Dr Coxe, the Scottish Lunacy Commissioner who supported the Society in advocating the Gheel system of boarding out voluntary patients. This was in direct opposition to Shaftesbury's English Board. ${ }^{87}$

Nevertheless, Walpole's Bills and the Select Committee's Report reflect the extent to which the Society's ideas had influenced government thinking. Walpole's Care and Treatment Bill, whilst avoiding the main issue behind the ALFS's campaign, a judicial hearing for every patient before admission, did propose, as Perceval had suggested, that all those detained should be visited within seven days and an independent report sent to the Commission. ${ }^{88}$ The Society was, in fact, wrong to blame Walpole's obstructionism for its lack of success in 1859, as he voted for many of its proposals when the Select Committee's Report was prepared. Rather, this Report fell by the wayside through the demise of the Tory government. When the Committee was considering Bolden's scheme to have a magistrate examine all certificates (as opposed to all patients) before admission, Walpole cast a deciding vote in favour, in direct opposition to Colonel Clifford (Tory MP and Lay Lunacy Commissioner) and Sir

\footnotetext{
82 The Society also obtained several clauses in the Scottish Lunacy Act 20 and 21 Vict c71 (1857) through its contacts with the Lord Advocate, notably the suggestion that clergy should visit local asylums on a regular basis. Also the enactment that before an admission, the relatives should sign a statement about the case, which, together with two certificates, would go to the local sheriff, to make an order. (It is interesting to note that in 1983, MIND was opposed to relatives being allowed to sign for the confinement of patients.) The above measure also permitted the voluntary confinement of nervous patients for up to six months.

${ }^{83}$ Sir William Tite 1798-1873. Architect; MP Bath 1855-73; FRS 1835. (See DNB.)

${ }^{84}$ As achievement: Hunter and Macalpine, op. cit., note 35 above. As failure: PRO/H045/0S/7269, Saumarez to Sir George Grey, 16 May 1862.

85 Spencer Walpole married Perceval's sister Isabella.

86 PR0/H045/0S/7269.

${ }^{87}$ For information on the Gheel system, see John Webster, 'Notes on Belgian lunatic asylums, including the insane colony of Gheel', J. psychol. Med. ment. Path., 1857, 10: 50-78 and 209-247; Henry Stevens, 'Insane Colony of Gheel', J. ment. Sci., 1858, 4: 426-437; W. L. Parry-Jones, The model of the Gheel lunatic colony and its influence on the nineteenth-century asylum system in Britain', in Scull (editor), op. cit., note 6 above, ch. 8.

${ }^{88}$ PP 1859, Sess. I, II, p. 117, ss 13 and 20. Known as the Examiners Bill. It took up the Society's idea that within three months, a patient's detention should be reviewed (s 14).
} 


\section{N. Hervey}

George Grey. ${ }^{89}$ That the ALFS failed to appreciate his contribution reflects not only the limited extent to which it was consulted, but also its ability to alienate even potential allies.

This rebuff in 1859 heralded a tapering down of the Society's work, but the influence of its ideas continued. Shaftesbury fought a strenuous rearguard action against the rising tide of belief that all should be afforded a jury trial or magisterial hearing before admission, but this was finally enacted in 1890 , four years after his death. ${ }^{90}$ Similarly, the voluntary admission of some patients, free passage of mail, employment of both sexes together on the nursing staff, and the licensing of nurses all came later. Unfortunately, they were adopted in a piecemeal fashion, rather than in a programme as the Society had intended, making it difficult to attribute any direct influence. It has also meant that the Society has been prominent only for its interest in certification. Its use of MPs and government went beyond merely obtaining legislative enactments, however, to a more educative role.

Wakley, for instance, used his position as a coroner to impart the ALFS's views. In 1848 , during one inquest, before a gallery packed with Society members and the press, he publicly criticized two Commissioners on defects in the Lunacy laws, utilizing the Society's arguments. ${ }^{91} \mathrm{He}$ also assisted with the advocacy of individual cases, helping obtain the return of one patient from confinement in Ireland and acting as a medical witness at his court hearing. In 1847, he led a vigorous parliamentary attack on the Commission over its handling of a scandal at Haydock Lodge Asylum. ${ }^{92}$ But his involvement was a mixed blessing. He parted company with other Society members where supremacy of medical men in this field was at stake, wishing to legitimate their influence whenever possible. In 1847, when Duncombe supported one of Perceval's Bills, Wakley sided with the Commission's representatives in the Commons, ridiculing its contents. The Bill aimed to afford the Church a greater role in the care of patients, to which Wakley's acerbic wit immediately found answer in the Lancet: "Lunacy", he wrote, "is already transferred from the profession of medicine, and handed over to the lawyers, to an extent which is highly prejudicial to the ... honour of medicine. The idea of giving the Bishops a finger in the pie could scarcely have orginated in any other than the brain of a lunatic." Evidently, Wakley's support was bought at some cost to Society members with personal experience of mental illness. ${ }^{93}$

Other MPs also lent support in canvassing Parliament, asking for Returns, ${ }^{94}$ and

\footnotetext{
${ }^{89}$ Grey had a proprietory interest in the Commission after nine years advising it. He had also served as a Metropolitan Lunacy Commissioner 1833-4.

90 The ALFS wanted compulsory detention under certificates to be complemented by the possibility of informal admission. In 1861, Dr Nesbitt, Superintendent of Northampton Hospital, wrote to Perceval criticizing the law, which ignored a person's will in the issue of confinement, enclosing a pamphlet addressed to Shaftesbury. (PRO/H045/0S/7102). It is true that the Acts 16 and 17 Vict c96, s6, and 25 and 26 Vict cII, s18 did allow some ex-patients to be received as boarders in private asylums, but this was a very limited provision; cf. Stanley Haynes, 'Voluntary patients in asylums', paper read at the Quarterly Meeting of the Medico-Psychological Association, 28 October 1869. (V \& A, Forster MSS, F 37 P 23, 559, No 9.)

91 Morning Post, 24 February 1848.

92 The Times, 28 August 1864; Morning Post, 27 August 1864; Morning Chronicle, 27 August 1846.

93 Lancet, 1847, ii: 56.

94 The only Returns asked for between 1845 and 1860 emanated from the Society. They were initiated by James Wyld in 1848, Henry Drummond in 1853, and William Tite in 1856 and 1858.
} 


\section{The Alleged Lunatics' Friend Society}

personally aiding patients, ${ }^{95}$ but the Home Office was the Society's major ally throughout this period. At the ALFS's insistence, it obliged the Commission to institute several changes. In 1850, for example, the Board omitted its customary list of asylum owners from its Annual Report, which elicited an immediate complaint to Sir George Grey, who got it restored. Keeping the Commission up to the mark was not enough though, and the Society had frequent recourse to the courts in individual cases, when its help was invoked.

\section{(II) USE OF THE Legal System}

In no other country than England, where private individuals perform so many of the local duties of government, would such a Society have even been imagined ... perhaps not one case in fifty will be brought to light by its exertions. But even the injustice of the remaining forty nine will be modified by its influenced. (The Atlas, 28 April 1847.)

From the outset, the ALFS had a strong legalistic bias, although it was never overly litigious. Its funds could no support the cost of regular court actions, and, as Perceval remarked in 1859, it had never "pretended that cases of unjust confinement were general, as compared with the number of persons confined as insane ... the lunatic asylum keepers would be spoiling their game if this were so."96 In fact, the Society was conspicuous by its absence from the most celebrated cases of dubious confinement in the mid-nineteenth century, most of which involved Chancery patients. Many of the actions it brought sought to highlight other infringments of patients' rights, within the context of legitimate admissions. In 1849 , for instance, two men were sentenced to six months' hard labour for defrauding a Bethlem patient of his savings. ${ }^{97}$ Nevertheless, the Society did come across many patients who were unnecessarily, if not illegally detained. In the face of obstruction from asylum owners, it generally resorted to the use of habeas corpus to bring these cases before the courts. However, its contact was often with discharged patients who wished to seek redress for their sufferings in asylums. These cases were not generally successful in obtaining compensation, but they did occasion proprietors acute embarrassment, especially if their asylums were criticized. ${ }^{98}$

It was the cases of illegal confinement that attracted most attention, however, despite evidence from several noted hearings that patients found sane and discharged were in fact quite disturbed. The well-publicized cases of Ruck, Leech, and Turner in 1858 and illustrate different aspects of this. Mrs Turner, who was detained at Acomb House, York, escaped and was recaptured in circumstances of considerable brutality. Her surgeon, Mr Metcalfe, admitted acting in a grossly improper manner and yet even

\footnotetext{
${ }^{95}$ Lord Dudley Stuart is a good example. He had a personal interest in the subject, having a son who was a patient of Drs A. Morison and E. J. Seymour. Stuart looked after his own son in private lodgings. (RCPE, Morison diaries, 16 and 17 May 1849). In 1848, he canvassed the Lord Advocate concerning the Scottish Lunacy Acts (Morison diaries, 18 May 1848). In 1853, he was instrumental in obtaining an inquiry into abuses at Colney Hatch, primed by the Society (HC Accounts and Papers 1852-3 (44) Vol C, pp. 45-50); and in 1854, he brought up the case of the Rev. Edmund Holmes at Heigham Retreat (PRO/H045/0S/5521).

${ }_{96}$ PP 1859, Sess 2, VIII, p.15.

97 The Times, 18 June 1848, p. 7. The case of Manuel Pimental, heard in the Central Criminal Court.

98 Ibid., 17 February 1852, p. 7, and 18 February 1852, p. 8. James Hill brought an action against Francis Philp, proprietor of Kensington House, for illegal confinement. Hill was clearly disturbed, and the jury found for Philp, but it also impressed on him that he should be taking a great deal more care in the management of his asylum.
} 


\section{N. Hervey}

Procter, a Lunacy Commissioner, expressed sympathy for him in having such an impossible woman to deal with. ${ }^{99}$ Leech was also a known eccentric, who was confined only after he decided to marry his servant, and relatives feared he might dissipate his inheritance. The public, though, questioned their motives. ${ }^{100}$ In Ruck's cases, it was agreed he was an alcoholic, but the controversy centred on the fact that John Conolly had issued his certificates of Ruck's lunacy after a joint medical examination, a clear violation of the law; and, more seriously, had received a free from Moorcroft House, where he was consulting physician, for referring Ruck to them. ${ }^{101}$ These and other cases in Chancery are interesting because they reflect, not only the shortcomings of medical testimony, but also the point at which various groups were prepared to define behaviour as insane. ${ }^{102}$

The only well-known cases the ALFS did show an interest in was that Louisa Nottidge, an heiress placed in an asylum to prevent her from giving her inheritance to a religious sect. Chief Baron Sir Frederick Pollock created a considerable stir in the psychiatric community with his concluding remarks in the case, when he stated the conviction that no person should be confined on the grounds of mental illness unless they were a danger to themselves or others. ${ }^{103}$ This elicited the Society's interest, as they hoped it would end the wholesale incarceration of harmless chronic patients, including epileptics and idiots, which had been occurring for some years. ${ }^{104}$ In practice, much of their work was concerned with these defenceless groups, who were unable to obtain help for themselves.

Between 1845 and 1863 , the Society took up the cases of at least seventy patients. ${ }^{105}$ Fundamental to its philosophy was the concept that patients should be allowed access to legal representation, and even encouraged to seek it. Like many localists, they were suspicious of the quasi-judicial powers afforded central Boards, such as the Lunacy Commission, to hold private inquiries and examine witnesses on oath. In theory, the Commission claimed that these were invariably held to decide on the merits of proceeding further to the courts, but in practice, they were conducted within a legalistic framework, whilst riding roughshod over the rules of evidence and prejudicing some patients' cases before they received a proper hearing. The Society complained that there was no representation for patients at these hearings, and no appeal from them, except to the Home Secretary, who would refer the matter back to the Commission. ${ }^{106}$

${ }^{99} \mathrm{~V}$ \& A Forster MSS, 48 F 65, Procter to Forster, letter dated 29 August 1857.

${ }^{100}$ For details see, J. L. and B. Hammond, op. cit., note 6 above, p. 205.

${ }^{101}$ See A. Scull, 'John Conolly: a Victorian psychiatric career', in Bynum and Porter (editors), op. cit., note 38 above, vol. 1, p. 45.

102 In An address on the laws of lunacy, 1854, p. 9, Saumarez attacked the way doctors generally denied that lunatics were responsible for their actions in court, and yet were prepared to punish them for minor misdemeanours in the asylum.

${ }^{103}$ PP 1849 XLVI, p. 381. Copy of the letter to the Lord Chancellor from the Commissioners in Lunacy concerning their duties and practice under the Act 8 and 9 Vict c 100; Also J. Conolly, A remonstrance with the Lord Chief Baron touching the case Nottidge versus Ripley, London, Churchill, 1849.

${ }^{104}$ The County Asylum Act of 1845 actually encouraged the incarceration of these groups. See Perceval's remarks in his edition of A. L. Pearce, Poems by a prisoner, London, Effingham Wilson, 1851, introduction.

${ }^{105}$ This figure is based solely on cases recorded in the Lunacy Commission's minutes. There were clearly others, as evidenced by the cases of Pimental and Beare, which were not mentioned by the Commission. 


\section{The Alleged Lunatics' Friend Society}

Often, asylum owners would make it difficult for patients to obtain legal advice, and the ALFS invariably had to approach the Commission when requested to act as counsel, because access to patients at their asylum had already been refused. In the face of these barriers, the society resolved that, wherever necessary, it would pursue cases into court, especially when particular points of law were concerned.

Unfortunately, in attempting to overcome the obstructionist tactics of the Commission, the Society sometimes exceeded its brief, giving opponents further opportunities to depict it as an irresponsible and harmful influence. In 1848, the ALFS was informed that a Mr Dixon was being wrongfully held at Northwoods Asylum. Bolden came to the Board to ask for copies of Dixon's certificates, one of which had been obtained after his admission. In the meantime, Dr Fox had discharged Dixon as "relieved", and almost immediately he was readmitted on correctly completed certificates. Dixon subsequently wrote to the Board to say that Bolden was acting without his sanction, ${ }^{107}$ although by this time Bolden had already applied for a writ of habeas corpus which then came to court. Although Dixon was found insane, the Society's attempt to cast doubt on the validity of his certificates, because both doctors had omitted the words "duly authorised to practise" after their names, brought this issue to public attention. Baron Alderson would not concede that the certificates were thus invalidated, but following this case, the Commission promoted legislation to ensure that medical qualifications were noted on certificates. Similarly, in 1848, Pulverstoft, a patient at Northampton Asylum, complained that the Society had approached the Lord Chancellor and Home Secretary against his wishes. ${ }^{108}$ Clearly, there is some disparity here between belief in self-expression and autonomy for patients and such a blatant invasion of their rights, which can only be explained by an overweening desire to expose practices at these two asylums. Nevertheless, this sort of tactic cast doubt on the Society's veracity and methods, and cost it much support.

In general, however, the ALFS's recourse to the judiciary met with a favourable response. a barmoeter of its success is provided by the Anstie brothers' case. These two subnormal men had been placed at Fishponds Asylum by their father. After his death, greedy relatives reduced the amount being provided for their care from a trust fund, necessitating their removal to the pauper section of the asylum. Gilbert Bolden applied to the Court of Chancery for a writ de lunatico inquirendo, placing the boys under the Court's care, to which the relatives responded with a counter-petition asking for the family to be appointed as their protectors. In general, courts were opposed to interfering in family affairs, but in this instance, the judge praised the Society's

\footnotetext{
106 For a more detailed instance of this type of criticism, see the complaints made by Bethlem's governors about the Commission's inquiry there in 1852. Bethlem Hospital, The observations of the Governors upon the report of the Commissioners in Lunacy to the Secretary of State on Bethlem Hospital. London, David Balten, 1852.

107 The initial referral came from a couple with whom Dixon had lodged for several years, saying he was not a proper person to be confined. (MH50/3, 5 July 1848.) At the time, the Lunacy Commission informed the Home Office that Fox had made an irregularity from a misapprehension of the law. (MH50/3 27 July 1848). However, during the inquiry into neighbouring Fishponds Asylum in 1848, more than fifty incorrect certificates were found at this asylum. The evidence taken on the inquiry into the management of the Fishponds Private Lunatic Asylum. Bristol, Joseph Leech, 1848, found in PRO/HO45/OS/2797.

${ }^{108} \mathrm{MH50/3}, 19$ May, 5, 13, 20, and 27 July, 3, 9, and 16 August.
} 


\section{N. Hervey}

concerned attitude and upheld its case, nominating Bolden to protect the brothers' financial interest. ${ }^{109}$ The sympathy of the legal profession is seen in several other spheres as well, notably in the Lord Chancellor's support for its appeals to the Lunacy Commission to release certain documentation. Caption Childe's case provides a good illustration. Childe was first confined as a single patient in May 1841, because of his delusion that Queen Victoria was in love with him. He was placed in a cottage near Regent's Park under Dr E. T. Monro's care and was subsequently moved to lodgings in Leamington Spa. In August, he was discharged from these after he appeared to have renounced his beliefs, but the following year, when stationed in Ireland, began to make threats against his senior officer, Lord Raglan, and was therefore consigned to Farnham House, Dublin. Ten years later, Wakley and Bernal Osborne (MP for Dover) had him returned to England at the Society's instigation, and placed at Hayes Park Asylum, near London, much against his father's wishes. Initially, Bolden made a considerable error of judgement in assessing that Childe was sane and competent to manage his affairs. ${ }^{110}$ Subsequently, however, he argued that Childe should either be discharged or his long-term detention formalized by a Commission de lunatico, which would provide some protection of his rights. Childe's family wanted to continue an indefinite detention with the minimum off publicity. ${ }^{111}$ Throughout the case, the Lunacy Commission acquiesced in William Conolly's opposition to the Society's interference, and correspondence to and from Childe was withheld by Conolly on several occasions, prompting Wakley to threaten a parliamentary inquiry. More importantly, the Lord Chancellor's aid was successfully invoked on three occasions, to obtain access for legal representatives, second medical opinions, and the copying of documentation. ${ }^{112}$ The Society was not always so fortunate, and was routinely refused access to information on technical grounds.

The legal profession also lent the Society considerable support in its wider aims. With ten lawyers amongst iots complement, it was well equipped, ${ }^{113}$ notably in the Court of Chancery. C. P. Villiers, the Free Trader, had been an examiner of witness there from 1833 to $1852,{ }^{114}$ and the Society's QC, James Russell, was also an expert in the same court. ${ }^{115}$ Russell primarily wanted to reform Chancery, and to that end had

\footnotetext{
109 For discussion of the case see PRO/HO45/OS/2797.

${ }^{110} \mathrm{See}$ PRO/HO45/OS/5490. Before applying to Chancery, Bolden tried to get Childe released because he was "illegally" confined on Irish certificates.

111 Childe's father had made an agreement with Sir George Grey that his son would only be moved from Ireland after consultation between himself and the incumbent Home Secretary. There were several features about this case which disturbed the ALFS, particularly the fact that in May 184!, Childe was seen in the Home Secretary's office by Sir J. Graham, Mr Hall (principal magistrate at Bow Street), and four doctors, who agreed on his confinement. He was unrepresented at this meeting, and remained so thereafter. PRO/HO45/OS/2726.

112 MH50/7, 11 May 1854, 9 and 15 June 1854.

113 George Hansard was an equity draftsman and conveyancer, as was Regnier Winkley Moore. Another useful member was Henry Francis Richardson, who was solicitor to a number of other societies, and let out premises cheaply to the Society.

${ }_{114}$ Charles Pelham Villiers 1802-98. Barrister. Contemporary at Lincoln's Inn of the Lunacy Commissioners Lutwidge and Mylne. MP Wolverhampton 1835-85. (See DNB.)

115 James Russell 1790-1861. Barrister with large practice in Chancery. To the probable embarrassment of the Commission, he had been a close colleague of Mylne's, co-editing several books on Chancery with him. (See DNB.)
} 


\section{The Alleged Lunatics' Friend Society}

joined the Society for Promoting the Amendment of the Law. ${ }^{116}$ It was through the auspices of Russell and Saumarez that the Law Amendment Society was approached in 1848. It was headed by former Lord Chancellors Brougham and Lyndhurst, both of whom had been heavily involved in previous lunacy legislation. They directed their Committee on Equity to examine the lunacy laws, and its subsequent report adopted a large number of the ALFS's proposals. ${ }^{117}$ In December the same year, Perceval wrote to Sir George Grey, enclosing a printed letter he had forwarded to Brougham as Chairman of the LAS. He hoped Grey would adopt some of his ideas in forthcoming legislation. Perceval quoted letters from F. B. Winslow and J. Conolly to the Morning Chronicle and Daily News respectively, which attacked the conclusions of the Equity Committee. Winslow disliked the suspicion cast on asylum proprietors, and claimed that it would be impractical for a jury to decide on the necessity of each admission, as laymen would be unable to distinguish the fine shades between disturbed and deranged intellects. Perceval, though, felt it indelicate that gentlemen who profited from patients' detentions should be the sole arbiters of these supposed fine shades. He also poured scorn on Winslow's references to habeas corpus as a safeguard, pointing out that patients were often refused access to an attorney, or their friends left unaware of their confinement. ${ }^{118}$

The interest taken in this issue by the LAS was a major coup for the ALFS, as the former included eminent lawyers amongst its membership, some of whom were in a position to affect the formulation of legislation, and others its implementation. The Equity Committee also concerned itself with asylum conditions and the property of lunatics. It made reference indirectly to the Society's work in Gloucester, ${ }^{119}$ and was firmly in favour of a "judicial" person visiting every patient soon after admission. Other recommendations that reflect Perceval's influence were more frequent visits by the clergy, a coroner's inquest on all asylum deaths, an enforced condition of residence on proprietors, and greater attention to the plight of single patients. ${ }^{120}$ These suggestions added to the increasing pressure on Shaftesbury to revise the lunacy laws, and were supplemented by support for the ALFS's campaign to reform lunacy proceedings in Chancery. ${ }^{121}$ Chancery had been responsible for the care of some lunatics and idiots since the middle ages. The king's authority had been vested in several courts, ${ }^{122}$ but the property of lunatics had constantly been embezzled and frittered away. Blackstone denied that the law was abused, but there undoubtedly was some basis for the reputation that Chancery had acquired. ${ }^{123}$ A system had evolved

\footnotetext{
${ }^{116}$ Hereinafter referred to as the Law Amendment Society (LAS). Henry Drummond was also a member.

117 Report of the Committee on Equity on the Law Respecting Lunacy, London, 1848.

118 PRO/HO44/52 Perceval to Sir George Grey, 21 December 1848.

119 Report of the Committee on Equity, pp. 15-16.

${ }^{120}$ Also mentioned were: a register of keepers, a greater strictness in granting licences, and the reduction of costs in Chancery proceedings.

121 William Carpenter 1797-1874. Writer and editor. Carpenter was appointed Hon. Sec. of the Chancery Reform Association 1851-3. (See DNB.)

122 'An Act Touching Idiots and Lunatiques', promulgated on 13 October 1653, for instance, stated, "the persons of idiots and lunatiques have received much damage, and their estates been much wasted and spoiled, since the four and twentieth day of February, One thousand six hundred and forty five (on which date the Court of Wards and Liveries, which had the care and protection of such persons was voted down) occasioned by the not settling of a way since the dissolution of the said court, for passing the Bills."
} 


\section{N. Hervey}

whereby interested parties petitioned the Lord Chancellor to inquire into the condition of an alleged lunatic. If there was a case to answer, he would a writ de lunatico inquirendo to the sheriff of the patient's county and the case would be tried before a jury. If the inquisition stood, his person and property were assigned to the care of Committees of the Person and the Estate. Often, these committees were vested in one person. ${ }^{124}$ This was an expensive process, and most commissions were put in suit concerning chronic patients, who were entitled to large estates. There was provision, by supersedeas, to reverse this process, but it was rarely invoked because of the long-term illness of the patients involved.

The campaign against Chancery was led by Saumarez, who had bitter personal experience of this court. His brothers Paul and Frederick had been placed under it by their father, but Richard was denied access to them refused permission to arrange second opinions from an independent doctor, and not kept informed when they were moved. ${ }^{125}$ Together with Bolden, Saumarez made repeated attacks on the endless expense of Chancery proceedings, which involved applications to the Masters in Lunacy, numerous affidavits and depositions, and fees for the preparation of all documents. ${ }^{126}$ They also criticized the fact that membership of Committees of the Person and Estate were bought and sold as investments, and the scandal that these bodies were not held accountable for their financial dealings. ${ }^{127}$ Former Lord Chancellors Lyndhurst and St Leonards supported this campaign, as did Brougham, who had long believed that visitation of Chancery patients by the Lord Chancellor's Medical Visitors was inadequate. ${ }^{128}$ Saumarez went so far as to allege that the Chancellor's Secretary of Lunatics actually falsified the Medical Visitors' reports, ${ }^{129}$ and argued strongly for an amalgamation of this Board of Visitors with the Lunacy Commission. Both administrations strenuously opposed such a move, although it might well have ensured some basic protection for Chancery patients within the minimum standards of care set up by the latter. The ALFS clearly believed that the Lunacy Commission could mitigate the worst practices of Chancery, but Shaftesbury knew that he would never get the willing co-operation of Chancery in such a joint enterprise. Despite its failure to obtain this unified service, the Society ensured a lengthy debate on the subject in 1859 , and undoubtedly influenced subsequent changes in 1862 , including increased visitation by the Medical Visitors, reduction in the expense

\footnotetext{
${ }^{123}$ Dickens described it as having "its decaying houses and its blighted lands in every shire, its worn out lunatic in every madhouse, and its dead in every churchyard." His lampooning of the proliferation of complex administrative procedures was entirely accurate. Charles Dickens, Bleak House, ch. 1.

124 These committees had to pay a bond, calculated on the estate, as a recognisance of good behaviour. Analysis of these suggests that many estates were gradually reduced in value. (PRO/J/103/1, 2, and 3.)

125 Saumarez, op. cit., note 43 above. p. 14.

126 PP 1852-3, XXV, 547. These returns on Chancery fees give some idea how costly proceedings could be. Saumarez spent over $£ 600$ on his brothers' case, including: $£ 25$ for an appointment of new committee, $£ 17$ for varying the maintenance, $£ 11$ for preparing leases, and $£ 17$ for grants of custody.

${ }_{127}$ Brougham tried to make them accountable in 1833. See PRO/LCO/11/1-last document in the file, dated 22 August 1833; See also, PP 1859, Sess. I, III, pp. 256-269. In one case, Drax vs Grosvenor, the Lord Chancellor ordered that an account be produced, and he was overturned by the House of Lords.

128 See, PRO/LCO/II/I Lord Brougham's letter dated 22 August 1833.

129 PP 1859, Sess. 2, VII, p. 4.
} 


\section{The Alleged Lunatics' Friend Society}

of application for a Commission, more accountability for Committees, and a clarification of the respective jurisdiction of the two bodies. ${ }^{130}$

The importance of these achievements and the Society's other work in the courts was that it continually posed questions about the adequacy of long-term care, whether in asylums, workhouses, or private lodgings. It was also the only group prepared to bring test cases to court in this area of civil liberties. Most Victorians preferred to keep the subject out of the public eye. Opposition to the ALFS's desire for a court hearing prior to admission sprang from motives other than social delicacy, however. The Society had researched legal systems widely, pointing out that in France, Belgium and Prussia ${ }^{131}$ patients were only confined after a judicial inquiry. Shaftesbury remained opposed to borrowing any scheme connected with the continental autocracies. Of the French conseil de famille, whereby a patient's family met the local magistrates to discuss certification and admission, he said in 1859, "if you read accounts of the system ... in France you would think that nothing could be more perfect... I think it is very doubtful if it is so." 132 There is little evidence, however, that he ever examined the practicality of foreign systems closely. Rather, he subscribed strongly to the prevailing belief that early admission was of vital importance to future cure, and felt a court hearing was inimical to this. Shaftesbury also refused to consider Perceval's suggestion that many patients could be admitted voluntarily, by-passing this difficulty. In thus appealing to a court hearing, the ALFS placed great faith in the local magistracy, and juries.

\section{(III) The Local Magistracy}

In the provinces, the local Quarter Sessions were responsible for appointing visitors to both public and private asylums, and it was to these visitors that the Society turned for help. This might appear surprising in view of Perceval's earlier comments about magisterial sloth and ignorance, and the ALFS certainly received a mixed response to its overtures. Perceval's faith in local justice was mainly based on the jury system, but he acknowledged that he had to work with the magistracy. Where inspection was concerned, he would have preferred to see local clergy doing the bulk of the visiting, believing that they would not come in as officials "representing the locks and keys which separate the patients from society, but come in as part of the neighbourhood, and repeat a little of the gossip of the day, and it would seem to supply a connexion with society." 133 The idea of more "open" institutions was one the Society always pursued, and it saw regular admission of the clergy and public as a real safeguard against abuses. Given the existing structure, however, the Society worked hard to promote more enlightened attitudes amongst local officials.

Whenever possible, members of the Society used their local connexions to exert influence, ${ }^{134}$ and they had definite strongholds in various areas of the country,

13025 and 26 Vict c III, The Lunatics Law Amendment Act. For further material on the arguments concerning amalgamation of the two, see PRO/LCO/1/64-67.

${ }_{131}$ Perceval was a personal friend of the Editor of Elberfelder Zeitung, who sent him debates in the Prussian Chambers on Lunacy, and whom he had visited. In 1850, the Society lobbied the US Ambassador, Mr Lawrence, seeking information. They also promoted the system used in Jersey.

132 PP 1859, Sess. I, III, p. 3.

133 PP 1859, Sess. II, VII, p. 44.

134 Perceval, Saumarez, and Bailey did this through their Poor Law positions. 


\section{N. Hervey}

including Bath, Northampton, Kent, Bristol, and Suffolk. Tracing the spread of their influence is difficult, except by means of specific examples. In 1848, they provided vigorous support to the campaign of Purnell B. Purnell, a local reformer and chairman of the Gloucester Quarter Sessions. ${ }^{135}$ Prompted by the Society, Purnell instituted a detailed inquiry into Fishponds Asylum, Bristol, previously considered amongst the leading institutions in the private sector. Many minor illegalities were discovered, coupled with palpable neglect and cruelty. Throughout $1848 / 49$, the effects of this inquiry were exploited. Local asylum proprietors objected strongly to this outside interference, and in 1849, the owner of Longwood House, Bristol, complained that a visiting magistrate, J. A. Gordon, had brought Perceval to the asylum on a visitation, and together they had inspected and personally examined several patients. ${ }^{136}$ The Lunacy Commission, whose primary concern was not with the good being effected, but with the establishment of a precedent that justices could introduce an outsider whilst carrying out their official duties, expressed disapproval and reported the matter to the Home Secretary. In its Annual Report the following year, the Commission afforded the Gloucester magistrates scant praise for their actions, and, of course, there was no mention of the ALFS's role in the sweeping improvements that were made. In 1850 , the Society set up a testimonial to Purnell which was well subscribed, and the Medical Times expressed the hope that other counties would copy this example. ${ }^{137}$

Evidence that Purnell's work, and indirectly the Society's, at Fishponds, Brislington, Ridgeway, and Longwood reached a wider audience can be found in correspondence to the Commission from a father complaining about the cruel treatment of his son at West Malling Asylum in Kent. He referred to Purnell, and listed a number of reforms he would like to see, all of which came directly from the Society's canon: a coroner's inquest on all asylum deaths; proprietors appointed by the government; more controls over private asylums; proprietors to spend more time with their patients; and a reduction in the turnover of attendants. ${ }^{138}$ This transmission of ideas can be found in a number of counties both directly and indirectly. In Kent again, for instance, Perceval corresponded with Lord Marsham, Chairman of the Quarter Sessions and a county asylum visitor. His letters were full of advice and useful criticism. He suggested a reduction of the long hours patients spent in bed, and opposed enlargement of the asylum, referring Marsham to articles on the subject. ${ }^{139} \mathrm{He}$ also floated the idea of cottage asylums on the model of Gheel in Belgium. The ALFS had long believed that half-way houses should be built where patients could stay before the need for formal admission arose or which could act as intermediary places of refuge on discharge from asylums. It was not alone in promoting the above schemes, but it was rare to find them being advanced as a package. Although some influence can clearly be inferred from subsequent developments at Kent, direct attribution is not possible. Following

\footnotetext{
135 Perceval had previous contacts with the Gloucester bench, having worked with the Rev. Edward Leigh Bennett, a visiting magistrate, to secure the discharge of William Bailey from Fairford House in 1842.

${ }_{136}$ MH50/4, 9 August 1849. See also PRO/HO34/9, 19 December 1849.

137 Medical Times, 28 January 1851. For the advertisement itself, see The Sun, No. 17,972, 1 May 1850.

138 MH51/44A, Letters from J. B. Player to the Commissioners dated 10 February and 11 May 1851.

139 Kent CRO, the Marsham Papers, U1515/OQ/L2, Perceval to Marsham, letters dated 10 May and 19 June 1858.
} 


\section{The Alleged Lunatics' Friend Society}

Perceval's comments, enlargement of the asylum was strenously opposed, and some years later, a system of detached cottages in the grounds was set up for convalescent patients.

The Society tried to educate local officials in other counties, and found that many were woefully ignorant. At Pickering, Yorks, the local Poor Law guardians were unaware that they were entitled to visit their lunatic paupers in the County Asylum, and Bolden remarked in 1859, that many magistrates had not heard of the Society when it contacted them. ${ }^{140}$ In many counties, the Society found it exceedingly difficult to obtain a list of the visiting magistrates, ${ }^{141}$ and even when the local authorities were aware of their legal obligations, both Society and Commission found that Town Councils and Poor Law guardians ignored them.

At Bath, Saumarez, from his position on the Council, carried out a long fight against the local workhouse ward for lunatics. Bath sent its acute patients to the County Asylum at Wells, ${ }^{142}$ and refused to build its own asylum, preferring to retain chronic patients and idiots in specialist workhouse wards. ${ }^{143}$ Saumarez's concerns went much further, however, than merely ensuring that Bath observed its obligation to build an asylum for its own paupers. Many other towns and boroughs ignored this duty. He was keen to ensure a proper level of care for pauper patients in the existing workhouse facility. Saumarez complained that there was no classification of the 135 idiotic, epileptic, and insane inmates there, no resident superintendent, no control over the nurses of whom there was an inadequate number, and a deficiency in the number of dayrooms. He had a running battle with R. T. Gore, the visiting surgeon, ${ }^{144}$ who denied the above allegations and was at a loss to explain Saumarez's four-year campaign to enlarge the airing grounds, in view of their "spaciousness". Despite Gore's denials, the Commission found substantial evidence of abuse and neglect. In 1859, Saumarez's complaints led to the sacking of John Cave, an attendant who had been stealing from the patients, and further correspondence in the 1860 s led to effective pressure from the Commissioners for change. ${ }^{145}$ Similar campaigns were carried out elsewhere, but in the face of intractable vested interests, the ALFS often had to resort to more forceful methods to publicize their work.

\section{(IV) The Press, Lectures, And Public Meetings}

Like most pressure groups the ALFS made what use it could of media coverage, possessing several useful outlets. Wakley's Lancet regularly carried articles criticizing the practice of doctors who hired out attendants for private nursing of the insane, and

\footnotetext{
140 PP 1859, Sess. I, III, pp. $230 / 1$ and p. 216.

141 Ibid., p. 215. Lists of these were first published for the whole country following Mr. Tite's request in Parliament in 1858. PP 1859, XXII, 175.

142 The Commission took exception to the contract under which this was done, because it had never approved it. (Bath City Record Office, MSS on Lunacy, letters dated 27 January 1855 and 23 August 1858. See also PRO/HO45/OS/6589, letters dated 4, 12, and 19 August 1858.

143 The latter were built in 1857 with the Poor Law Board's blessing, but without consulting the Lunacy Commission. Saumarez did, however, inform Walpole of this via Perceval. (PRO/HO45/OS/6589 Saumarez to Perceval 26 October 1858.)

144 It is clear that Gore and the mayor were working together against Saumarez. Bath City Records, Lunacy MSS, letter from Gore to the mayor, 1 August 1862.

145 Tite also took part in this campaign, writing to Grey. Ibid., 23 December 1862.
} 


\section{N. Hervey}

made use of physical coercion with patients. Often, these pieces contained some accreditation to the Society, ${ }^{146}$ which also received support from other members. Peter Borthwick $^{147}$ was editor of the Morning Post, James Russell co-edited the Annual Register, and William Carpenter the Sunday Times. Others merely contributed by forwarding letters to various papers and journals, although several, like the Medical Times, were inconsistent in their coverage. ${ }^{148}$ Generally, the issue of illegal incarceration of the sane brought a chorus of support, but other suggestions for improvements often attracted derision.

In order to counter adverse publicity, the Society also promoted its views through public meetings and lectures, which were often poorly attended. These were held to mount specific campaigns in Parliament, ${ }^{149}$ but the Society also used them in conjunction with attacks on particular institutions. Their assault on Northampton Hospital is typical in this respect. An old subscription hospital, Northampton had failed to keep pace with the innovations in county asylums. The ALFS attempted to publicize the illegal admission of a patient there in 1848, and had long suspected the existence of abuses. ${ }^{150}$ In July 1857 , their allegations led to the sacking of three attendants, although evidence as to Dr Nesbitt's drunkenness was omitted from the Lunacy Commisssion's report to the Home Office. The local magistrates subsequently exonerated Nesbitt in their own inquiry. A year later, the Society obtained another inquiry, after pressure on the Home Office and Commission following a death at the asylum. Perceval produced witnesses (patients) and conducted their examination, but nothing was proved. Finally, unable to get the case reopened, Perceval resorted to a campaign in the local press and delivered a lecture "against" the hospital in Northampton Town. This had the desired effect when new staff were appointed, and a fresh treatment regime, in line with the Commission's views, was instituted. ${ }^{151}$

The use of public meetings and lectures appealed to Perceval's extrovert personality, and it is clear that at times the horror of his own experience and feeling of rejection was indiscriminately applied to the situations of those he was trying to help. The atmosphere at his lectures bordered on the histrionic, with ex-patients freely making serious allegations against asylums like Hanwell and Colney Hatch. Even the presence of such doctors as Conolly and Lockhart Robertson did not deter them. It was a different matter when the Society's supporters attended other meetings. William Cole, ex-patient of Fisherton House, told Perceval he had been frightened to address a

\footnotetext{
146 Lancet, 1847 , i: $82 ; 1848$, i: 433,$678 ; 1852$, ii: 13.

147 Peter Borthwick 1804-52. MP Evesham 1835-47. Barrister 1847. Editor, Morning Post, 1850-52. (See DNB.)

148 The Society could not rely on favourable coverage in the medical journals. Compare, for instance, Med. Times, 1848-49, 19: 68, with ibid., NS. 2: 4 January 1851.

149 E.g. the meeting held on 28 March 1848 at the British Coffee House to prepare a petition asking for a Select Committee. See advertisements in The Times, 25 and 28 March 1848; Also meeting on 1 February 1859 at Exeter Hall. See Morning Post, 3 February 1859; and Br. med. J., 1859, i: 116-117.

${ }_{150}$ MH50/3. Entries between 19 May and 27 July 1848 for Mr Pulverstoft.

151 MH50/9, 8 July-31 August 1858. One of the governors tried to discredit Perceval by arguing that his history of mental illness implied that "his sympathies with the insane are of a very morbid character and his judgment to the last feeble and weak." (Northampton Herald, letter to the editor from George Robinson, 4 September 1858. Cf. ibid., 28 August 1858 for text of Perceval's lecture. A complete account can also be found in PP 1860, LVII, 959.)
} 


\section{The Alleged Lunatics' Friend Society}

meeting chaired by Shaftesbury in case "his expressions might be taken advantage of, in his state of poverty to shut him up again." 152 There was a very real danger of this, as he had already been apprehended from outside the Commission's offices on one occassion. Perceval was undeterred, and the personal nature of many of his attacks ruined what reputation the Society might have gained for objectivity. It is not clear exactly where the boundary between Perceval's role as a private citizen and as a member of the Society lay, but in putting forward its ideas he was also venting his own frustrations with society and convention. Nevertheless, the ideas still shone through. In 1850, Perceval delivered a lecture intended to redress a loophole in the law, which failed to empower the authorities to apprehend a wandering lunatic if he was not a pauper. It took place at the King's Arms, Kensington, and centred on the case of Lieutenant Frederick Mundell, an army officer whose persecutory belief was that his promotion had deliberately been blocked. ${ }^{153}$ Mundell spent most of his time wandering in London seeking redress from Queen Victoria, Wellington, and Lord Raglan. He was thought to be potentially dangerous, and two detectives were assigned to follow him everywhere. As a result of defects in the law, Mundell had spent three periods in prison, before a relative was finally persuaded to sign an order for his confinement in Wyke House. Perceval spared no one in his attack on the authorities, likening Richard Mayne, the Police Commissioner, to a serpent crawling all over Mundell, and calling for the police to be placed under the control of the ratepayers and not used as spies like those in France and Russia. Clearly, Perceval exaggerated the wrongs done to Mundell, and made light of his evident disturbance. ${ }^{154}$ Nevertheless, his actions, which included writing to and seeking interviews with Mayne and the Home Secretary, added to pressure the police were already exerting on the Lunacy Commission and government, and contributed materially to the enactment of clauses in 1853 to rectify the law. ${ }^{155}$

It is difficult to estimate exactly how extensive the ALFS's activities were, because public meetings constituted only a small part of its activities, but it certainly became identified as a repository for complaints concerning psychiatric practice from all over the country. In a number of instances, it monitored particular institutions over a period of years, ${ }^{156}$ and consistently drew attention to abuses the Commission was unaware of despite its inspections. What then was the Society's importance, and how should it be assessed in the light of its relationship with the psychiatric establishment and Shaftesbury's Board?

\section{ConcLusion}

Following the 1859 Select Committee, the Society continued to approach the Home Office and Commission for several years, but its activities came to a natural end in the

\footnotetext{
152 PRO/HO45/OS/7102 letter Perceval to Clive, 27 May 1861. See also V \& A Forster Papers, 48 E 32, Procter to Forster, 11 April 1862.

153 For detailed correspondence on this case see PRO/MEPOL/289, and MEPOL/3/20 and 21.

154 Mundell carried pistols about with him, went to bed with his boots on, slept indiscriminately with prostitutes, exposed himself to his landlady, and became passionately angry when he lost his belongings.

${ }^{155}$ See PRO/HO45/OS/2222 for Police and Lunacy Commissioners' correspondence with the Home Office.

156 This was true of both Hanwell and Colney Hatch, as well as Northampton Hospital. For Colney see PP, HC, Accts and Papers, 1852-3, (44), vol C, pp 45-50, and MH50/10, 1 August 1860.
} 


\section{N. Hervey}

mid-1860s with the deaths of key members. Bolden died in 1864, and Saumarez in 1866. In addition, Perceval had lost three brothers between 1856 and 1861 , and one suspects that the appointment of his nephew Charles Spencer Perceval as the Lord Chancellor's secretary in 1866, and later as secretary of the Lunacy Commission, finally gave him some peace of mind. ${ }^{157}$ Assessment of the Society's impact is not easy. I propose here to examine reactions to the Society from the medical profession and Commission, before attempting a final appreciation.

Medical practitioners certainly viewed the Society with a mixture of apprehension and admiration. In the $1850 \mathrm{~s}, \mathrm{~T}$. H. Tuke, owner of Manor House, Chiswick, told Perceval, after his visit to the Chartist leader Feargus O'Connor, ${ }^{158}$ "I assure you I would rather see the devil in my asylum than you." This feeling was inspired by the fact that Perceval had already cost him a patient worth $£ 300 \mathrm{pa},{ }^{159}$ and is representative of the trouble this Society visited on many asylums. In 1857, it complained of cruelties at Fisherton House, to which the Commission replied, on investigation, that it was satisfied with Dr Finch's unqualified denial of the alleged abuses. Given Finch's refusal to assist and the Commission's response, the Society abandoned its inquiry. A year later, however, the Commission castigated Finch for using a "ducking bath" and for generally neglecting to spend time with his patients, leaving them mostly in the hands of attendants. ${ }^{160}$ Often, doctors highlighted the Society's intrusive methods, as a way of gaining the Board's support, ${ }^{161}$ but frequently, their motives stemmed from fear of exposure, rather than concern for the patients' welfare. The Board was often forced to act by the weight of evidence the Society produced, but it disliked having to dance to the latter's tune. Occasionally, in attempting to avoid this, the Commission missed important cues. In 1851, Mr Watson, the proprietor of Heigham Retreat, Norwich, asked the Board whether he was obliged to answer the society's inquiries about a patient, and presumably elicited the hoped-for response that it was open to his discretion. Later, substantial irregularities were uncovered at Heigham, but only thanks to Lord Dudley Stuart, who brought up the issue in Parliament for the Society. ${ }^{162}$

Many practitioners, however, did believe that the Society served a useful purpose. Dr Nesbitt, who had less reason than most to support it after its attacks on Northampton, wrote to Perceval in 1861 about the need for an act legalizing voluntary admissions. He remarked, "I deem you to be the great pioneer to whom we are

${ }^{157}$ Dudley Montagu 1856, Spencer 1859, and Frederick James in 1861. Charles Spencer was Dudley's eldest son. The connexions of the Perceval family with the subject of lunacy seem quite endless. In 1870, Spencer's widow sold Elm Grove Asylum, Ealing, to the East India Company. It is not clear how long she had owned the asylum. (India Office Library and Records, Hailebury Records J-K, L/Mil/9.)

158 PP 1859, Sess. 2, VII, p. 22.

159 This patient was removed by the Commissioners following Perceval's allegations of neglect, MH50/10, 17 November 1858.

160 Compare entries in the Board's Minutes, MH50/8, 11 March 1857, and MH50/9, 30 March 1858.

161 In April 1854, William Conolly claimed that Bolden's frequent visits and correspondence were upsetting Captain Childe, and interfering with his treatment at Hayes Park. One might ask though why the Commission allowed such an unsavoury character to practise at all? Three years earlier, they had refused to renew Conolly's licence because he had taken unwarrantable sexual liberties with a female patient. (MH50/7, 27 April 1854, and MH50/5, 17 December 1851.)

162 MH50/5, 10 April 1851. Also PRO/HO45/OS/5521. Correspondence re the Rev. Holmes. In fact, the Board was aware of previous irregularities, as a doctor was forced to leave in 1849 after getting one patient pregnant and assaulting another, MH50/3, 11 January 1849. 


\section{The Alleged Lunatics' Friend Society}

indebted for the initiation of various beneficial changes, I wish to ask whether you could through your parliamentary influence, obtain a glimmering into the future as sketched by me in the accompanying memorandum." ${ }^{163} \mathrm{G}$. S. Ogilvie was another who sought the Society's help to promote such a scheme after being hounded by the Commission for taking uncertified voluntary boarders. ${ }^{164}$ Such supporters could be a mixed blessing, especially if, as seems likely, they were only seeking their own advantage in obtaining patients who would have no protection in the form of official certification and visitation. In 1859, the private asylum owners within the Asylum Officers Association invited Bolden to present the Society's proposals at their meeting to discuss Walpole's bills, and a few of these were adopted. At this meeting, Conolly, who had come to believe that public asylums were exhibiting many of the faults foreseen by Perceval, argued that more notice should be taken of the Society's views, ${ }^{165}$ and others had clearly given thought to its schemes as outlined in Walpole's bills. But it was the Commission ultimately that the Society had to influence.

The Society's importance lies in the wide panorama of ideas it laid before Shaftesbury's Board. Unrestrained by the traditions of bureaucratic office, it was free to explore a variety of alternatives for care of the insane, many of which were too visionary or impolitic to stand a chance of implementation. The difficulty it faced was the blinkered perspective of the Commission and of Shaftesbury in particular. ${ }^{166}$ Some Commissioners showed themselves favourable to the Society's policies, but were restrained by the general tenor of Board policy from expressing this. Among the interesting ideas already mentioned were the licensing of attendants, sealed post boxes in asylums, and increased contact between the sexes within each institution. These ideas could have contributed materially to the welfare of patients, and all resurfaced later. All three had advantages that appealed to the Commission and even to the medical profession. The first might have prevented the high turnover of attendants in most asylums and discouraged poorer applicants, the second would have ensured the privacy of patients' communications, preventing abuse, and the third ought to have reduced the dreary institutionalization of asylum life. Unfortunately, all possessed disadvantages which a cautious bureaucracy could not gainsay. The first constituted an interference in private enterprise and the principle of laissez-faire, the second offended medical control of affairs in the asylum, and the last was inimical to Shaftesbury's moral beliefs.

Shaftesbury, with his overly sensitive nature, saw the Society's activities as a standing reproach to his Commission, and therefore promoted an obstructionist response to them, typical of the bureaucracies lampooned by Dickens in Little

${ }^{163}$ PRO/HO45/OS/7102, Nesbitt to Perceval, 24 May 1861. Nesbitt and his wife left Northampton in 1859 , and had great difficulty in obtaining a licence from the Commissioners. Nesbitt would certainly have benefited from any moves to allow voluntary patients, and it was because of characters like him that the Commission was reluctant to permit informal admission.

${ }_{164}$ Ogilvie had been forced to move asylums several times, because he kept voluntary patients illegally. In 1851, he was refused a licence for Blythe House, Turnham Green, by the Commissioners. See PP 1859, Sess. II, VII, p. 35. Also MH50/5, 12 June 1851.

165 J. Ment Sci., 28 February 1859, 5: 392.

166 For a description of Shaftesbury's views, see Hervey op. cit., note 64 above, pp. 181-184. Also Finlayson op. cit., note 13 above, pp. 559-609. 


\section{N. Hervey}

Dorrit. ${ }^{167}$ The Society was refused copies of patients' certificates on minor technicalities, and Bolden claimed that the Board actually laundered those copies it did issue. Certainly, the Society was never given one which did not provide a legal justification for detention. The Society received shabby treatment from the Board in other respects too. In 1858, Saumarez reported the existence of an uncertificated patient confined in Hampshire. Normal Commission policy was to protect the identity of informants, and yet in this case it revealed Saumarez's name as its source. ${ }^{168}$ The same year, Saumarez reported the death of a patient due to ill-usage at Surrey County Asylum, intimating that Perceval had also written to the Home Office. A full ten days later, one of the Commissioners consulted Shaftesbury, who was of the opinion that, "as Admiral Saumarez had stated that the matter had been brought under the notice of the Home Secretary, the Board should not take any step at present-but that if any communication was received from the Home Office, two Commissioners should at once visit."169 Clearly, this course, whilst leaving initial investigations to the local visiting magistrates, might well be constructed as negligent, not to say dismissive of the Society's information.

Despite these slights, the Commission did sometimes thank the Society for its contributions, and the latter must undoubtedly take some responsibility for the hostile attitude of others. Often it lacked subtlety, inviting rejection and disparagement. The collective membership were not entirely blameless either, in that they endorsed the inclusion of Perceval's more ridiculous ideas in bills and petitions to eminent figures of the day, which naturally diluted the impact of their other proposals. In any assessment of a pressure group, the danger lies in overvaluation of its contribution, but in this instance there is the added pitfall of becoming enmeshed in the persecutory flavour which the Society imparted to all comment on its activities. Their undoubted contribution was to exert continuous pressure on the Commission during its first twenty years in office, causing constant reappraisal of its policies. It was the Society's misfortune that myths about mental illness at this era were prejudicial to its advanced thinking, but it was able to provide substantial support to individual patients, and initiate inquiries into the management of numerous asylums. Its work in several fields, e.g., Chancery reform, the plight of criminal lunatics, ${ }^{170}$ and improvement of asylums conditions, has never been acknowledged, and altogether it deserved better support than it attracted.

Clearly, the Society is also very significant as the first organized manifestation of public apprehension about operation of the lunacy laws. Although it did not feature in the most celebrated cases of wrongful confinement, its espousal of further safeguards in admission procedures, invoking traditional legal rights, was something that had

\footnotetext{
167 In 1859, Perceval remarked that they had never taken a liberal view of their duties, proceeding by remedies of cure rather than those of prevention. See Charles Dickens, Little Dorrit, ch. 10.

${ }^{168}$ MH50/9, 14 September 1858.

${ }_{169}$ MH50/10, 5 and 15 October 1858. See also MH50/13, 6 September 1864.

${ }^{170}$ Saumarez complained in 1859 to the Select Committee that criminal patients who were transferred from prison to asylums were often kept there after their sentences had expired, sometimes for up to fifteen years. He felt they should have regular medical reviews of their condition and complained that the Home Secretary and Board refused him access with a doctor to assess patients and yet would not discharge them without medical evidence. (PP 1859, Sess. 2, VII, pp. 11-12.)
} 
appeal. McCandless's study, although demonstrating that there were few wrongful confinements of the sane, did not fully highlight the situation of many unwell people who were unnecessarily confined by their families. ${ }^{171}$ In 1859 , J. S. Mill criticized the "contemptible and frightful" evidence on which people were declared unfit to manage their own affairs. His point, and the Society's, was that medical prerogatives had expanded definitions of insanity to a point at which they encroached on the borders of eccentric, immoral, and even criminal behaviour. Roger Smith has illustrated how the concept of responsibility was gradually eroded by alienists' medicalization of crime, and the ALFS was concerned that a similar process was occuring with the epileptic and mentally subnormal. It was critical of the 1845 County Asylum Act, which encouraged the confinement of these groups, seeing it as quite unnecessary in most cases. However, it was not possible for such a small group to do more than raise consciousness about the poor level of asylum care, and question the growing faith placed in medical expertise. Scull's work has demonstrated the element of social control inherent in the county asylum system, and Perceval, too, made a great deal of this. But one suspects that the vast majority of those confined were sufficiently ill to justify detention, and that the usefulness of an organization such as this was continually to challenge the parameters of mental illness laid down by others. Curiously for a movement which often sought publicity, the ALFS did most of its effective work out of the limelight, in constant exchanges with the Home Office and Lunacy Commission. Given the general lack of public interest in lunacy, it is doubtful whether the Society could ever have attracted widespread support, but its limited following can be attributed in part to the reputation it gained for intrusive and insensitive investigations. At times, it overstated its case, but more often than not, very real abuses were uncovered, and it would not be an exaggeration of the Society's worth to say that patients' rights, asylum care, and medical accountability all suffered with its demise in the 1860s.

171 The ALFS highlighted many cases like that of Miss Mackray, whom they reported as under restraint as a lunatic in a house in Upper Holloway, since her discharge by order of the Board from Elm House, Chelsea. Miss Mackray was clearly ill, but not in need of confinement. MH50/9, 4 August 1857. 